bioRxiv preprint doi: https://doi.org/10.1101/2021.11.05.465756; this version posted November 5, 2021. The copyright holder for this preprint (which was not certified by peer review) is the author/funder, who has granted bioRxiv a license to display the preprint in perpetuity. It is made available under aCC-BY 4.0 International license.

\title{
Long-term fungus-plant co-variation from multi-site sedimentary ancient DNA metabarcoding in Siberia
}

Barbara von Hippel ${ }^{1}$, Kathleen R. Stoof-Leichsenring ${ }^{1}$, Luise Schulte ${ }^{1}$, Peter Seeber ${ }^{2}$, Laura S. Epp ${ }^{2}$, Boris K. Biskaborn ${ }^{1}$, Bernhard Diekmann ${ }^{1}$, Martin Melles ${ }^{3}$, Luidmila Pestryakova ${ }^{4}$, Ulrike Herzschuh ${ }^{1,5,6 *}$

1 Alfred Wegener Institute Helmholtz Centre for Polar and Marine Research, Polar Terrestrial Environmental Systems, Potsdam, Germany

2 Limnological Institute, Department of Biology, University of Konstanz, Germany

3 Institute of Geology and Mineralogy, University of Cologne, Germany

4 Institute of Natural Sciences, North-Eastern Federal University of Yakutsk, Yakutsk, 677007, Russia

5 Institute of Environmental Science and Geography, University of Potsdam, Germany

6 Institute of Biochemistry and Biology, University of Potsdam, Germany

*corresponding author

Keywords: ancient DNA metabarcoding, fungus community changes, ITS marker, fungus-plant covariation, Siberia

\footnotetext{
Abstract

Climate change has a major impact on arctic and boreal terrestrial ecosystems as warming leads to northward treeline shifts, inducing consequences for heterotrophic organisms associated with the plant taxa. To unravel ecological dependencies, we address how long-term climatic changes have shaped the palaeo-ecosystems at selected sites in Siberia.

We investigated sedimentary ancient DNA from five lakes spanning the last 47,000 years, using the ITS1 marker for fungi and the chloroplast P6 loop marker for vegetation metabarcoding. After bioinformatic processing with the OBItools pipeline, we obtained 706 unique fungal operational taxonomic units (OTUs) and 243 amplicon sequence variants (ASVs) for the plants. We show higher OTU numbers in dry forest tundra as well as boreal forests compared to wet southern tundra. The most abundant fungal taxa in our dataset are Pseudeurotiaceae, Mortierella, Sordariomyceta, Exophiala, Oidiodendron, Protoventuria, Candida vartiovaarae, Pseudeurotium, Gryganskiella fimbricystis, and Trichosporiella cerebriformis. The overall fungal composition is explained by the plant composition as revealed by redundancy analysis. The fungal functional groups show antagonistic relationships in their climate susceptibility. The advance of woody taxa in response to past warming led to an increase in the abundance of mycorrhizae, lichens, and parasites, while yeast and saprotroph distribution declined. We also show co-occurrences between Salicaceae, Larix, and Alnus and their associated pathogens and detect higher mycorrhizal fungus diversity with the presence of Pinaceae. Under future warming, we can expect feedbacks between fungus compositional and plant diversity changes which will affect forest advance and stability in arctic regions.
} 
bioRxiv preprint doi: https://doi.org/10.1101/2021.11.05.465756; this version posted November 5,2021 . The copyright holder for this preprint (which was not certified by peer review) is the author/funder, who has granted bioRxiv a license to display the preprint in perpetuity. It is made available under aCC-BY 4.0 International license.

\section{Introduction}

Fungi represent a principal component of soils and sustain a broad variety of ecosystem functions (Frąc et al., 2018) that are highly dependent on the fungal composition and are subject to changing environmental conditions. For example, experimental warming led to an increase in ectomycorrhizal fungi and free-living filamentous fungi, while a decrease in yeast was observed (Treseder et al., 2016). Besides, experimental warming showed an increase in the evenness of fungal tundra communities, including a significant increase in ectomycorrhizal fungi in relation to rising temperature (Deslippe et al., 2012). Furthermore, under warming, saprotrophs shifted their metabolism from decaying wood to self-maintenance and subsequent spore-production (Romero-Olivares et al., 2015; 2019). It has also been reported that warming leads to an increase in specific plant pathogens (Otrosina and Cobb, 1989). Accordingly, time-series on compositional changes of fungal communities during past climate changes are highly valuable to assess the potential shifts of ecosystem functioning in a rapidly warming world. Time-series are also an asset when testing whether lab experiments reflect real natural developments on long geological timescales.

Fungal functional types reflect the strong interactions between plants and fungi but we are far from understanding the detailed processes involved in particular temporal changes in their covariation (Zobel et al., 2018). These types help group fungi according to their functional roles in the terrestrial ecosystem allowing the assessment of compositional shifts. This, however, remains a challenging task as the ecological functions of many taxa are still not understood. The major ecological functional fungus groups in forest ecosystems are saprotrophs, mycorrhizae, and parasites. Saprotrophic species are major decomposers in terrestrial ecosystems (Baldrian and Valášková, 2008). A plant's benefit from mycorrhizal fungi is the enabled acquisition of mineral nutrients in solution, such as phosphate, while the fungus in return receives carbohydrates from the plants (Finlay, 2008). Mycorrhizal fungiplant associations include arbuscular mycorrhizae, ectomycorrhizae, ericoid mycorrhizae, and orchid mycorrhizae (Brundrett and Tedersoo, 2018). Parasitic fungi, such as Heterobasidion, infecting conifer tree taxa (Garbelotto and Gonthier, 2013), are important for eliminating weak trees to maintain the functioning of healthy forest ecosystems. Biotrophic plant parasites feed from living tissue while necrotrophic fungi penetrate the plant, destroy the tissue, and subsequently provoke plant death (Naranjo-Ortiz and Gabaldón, 2019).

Boreal forests are the world's largest biome and cover an area of around $9 \%$ of the total land mass between $45^{\circ}$ and $70^{\circ}$ north (Czimczik, 2005). These ecosystems are an important habitat for fungi and in particular arbuscular mycorrhizal fungi (Öpik et al., 2008). Ectomycorrhizal communities in the subarctic tundra are generally species-rich but do not show a high host preference (Ryberg et al., 2009; 2011). Nevertheless, for the establishment of these mycorrhizal associations, fungal preferences towards distinct plant families or even species were detected. For example, Glomus intraradices (Smith et al., 1998; Wagg et al., 2008) and also Suillus species have been found to predominantly build up mycorrhizal associations with Pinaceae (Palm and Stewart, 1984; Wagg et al., 2008; Liao et al., 2016). Therefore, the ongoing invasion of woody taxa into tundra areas due to global warming should impact fungus composition. Furthermore, deep DNA sequencing studies of soil fungi in arctic Alaska revealed that warming does not affect overall fungus richness but leads to a change in the community composition. The results of these studies revealed that a decrease in ectomycorrhizae, ericoid mycorrhizae, and lichens in the tundra accompanied an increase of saprotrophic, pathogenic, and root endophytic fungal richness (Geml et al. 2015; Mundra et al. 2016). Hitherto almost all information on fungal compositional turnover originates from short-term warming experiments. Therefore, it is necessary to analyse long-term changes in plant-fungi covariation under natural conditions in different settings including different time scales to include potential lags of vegetation responses towards shortterm warming.

Compositional changes of vegetation and associated fungal communities are slow. They occur on decadal, centennial, or even millennial time-scales which are not covered by the, anyway, rare observational time-series and thus the exploitation of palaeoecological archives is required. As large 
bioRxiv preprint doi: https://doi.org/10.1101/2021.11.05.465756; this version posted November 5,2021 . The copyright holder for this preprint (which was not certified by peer review) is the author/funder, who has granted bioRxiv a license to display the preprint in perpetuity. It is made available under aCC-BY 4.0 International license.

parts of Siberia were not covered by glaciers during the Last Glacial Maximum (Svendsen et al., 2004), lakes from this region provide sedimentary archives which continuously cover the rather warm marine isotopic stage (MIS) MIS 3 (50-30 ka), the cold MIS 2 (30-15.5 ka), and the warm Holocene (MIS 1) (the last $11.6 \mathrm{ka}$ ) (Kreveld et al., 2000; Swann et al., 2005), thereby encompassing tremendous vegetation changes. Lake sediments represent natural archives of terrestrial environmental change (Courtin et al., 2021). Given that northern Russia is warming faster than the global average (Biskaborn et al. 2019), lake sediments can provide valuable information on the associated terrestrial ecosystem changes. While many sedimentary pollen records focus on vegetation change, there is limited information about fungi (e.g. from non-pollen palynomorphs (Van Geel, 2001)) as they lack a morphological fossil record.

Sedimentary ancient DNA metabarcoding (sedaDNA) is a promising palaeoecological proxy method which makes use of specific genetic marker regions enabling the study of past biodiversity (Sønsteb $\varnothing$ et al., 2010). So far, many sedaDNA studies have investigated plant metabarcoding, mostly applying the trnL P6 loop marker (Parducci et al., 2017; Alsos et al., 2018; Liu 2020), but there are only few studies focusing on fungal ancient DNA from sedimentary deposits (Lydolph et al., 2005; Bellemain et al., 2013; Talas et al., 2021). Bellemain et al. (2013) traced past fungal communities in Siberian permafrost sediments. In addition to permafrost, lake sediments can also be used to investigate past ecosystem dynamics. Through relocation processes, the environmental DNA is continuously deposited in the lake which favours these sediments over soil profiles. Recently, Talas et al. (2021) investigated lake sediments showing clear variations in the community compositions: while saprotrophs remained stable over time, host-specific fungi such as plankton parasites and mycorrhizae shifted in relation to human impact and changing climate. The internal transcribed spacer (ITS) region is the most commonly used DNA barcoding region for fungi (Seifertt, 2009), but the primers that were used in early studies caused quite some amplification biases (Bellemain et al., 2010). Primers to specifically target ancient and degraded DNA were designed and used on permafrost deposits (Epp et al., 2012; Bellemain et al., 2013). These have now been refined according to the current status of reference databases by Seeber et al. (2021), providing a primer pair that is highly suitable to amplify sedaDNA as it targets short amplicons of a mean length of $183 \mathrm{bp}$ and is highly specific towards fungi. This enables now studies using sedaDNA to trace fungus-plant interactions over time.

The aim of this study is to analyse lake sediments from five sites in Siberia spanning MIS 3, 2, and 1 for their fungal composition using sedaDNA metabarcoding with the ITS1 marker. The obtained data are compared to vegetation data gained from metabarcoding with the trnL P6 loop marker on the same samples. This study addresses the following questions: (1) How does fungal alpha diversity change during tundra-forest transitions? (2) How do fungal taxonomic composition and function change relative to vegetation transition? Based on the answers, we draw conclusions on fungus-plant covariation under climatic changes over long timescales. These results will help to improve predictions of the response of fungus-plant interactions to future warming.

\section{Geographic setting and study sites}

All study sites are located within Siberia, central eastern Russia (Figure 1), and are characterised by permafrost soils (Brown et al. 1997; Tchebakova et al., 2009). The climate in the entire area is rather continental with hot summers and long, severe winters (Atlas Arktiki, 1985). The most prevalent vegetation is boreal forest with spruce, pine, fir, and larch in the western and southern parts and pure larch forest in the east. The arctic regions along the coast and on the Taymyr Peninsula are covered by tundra. 

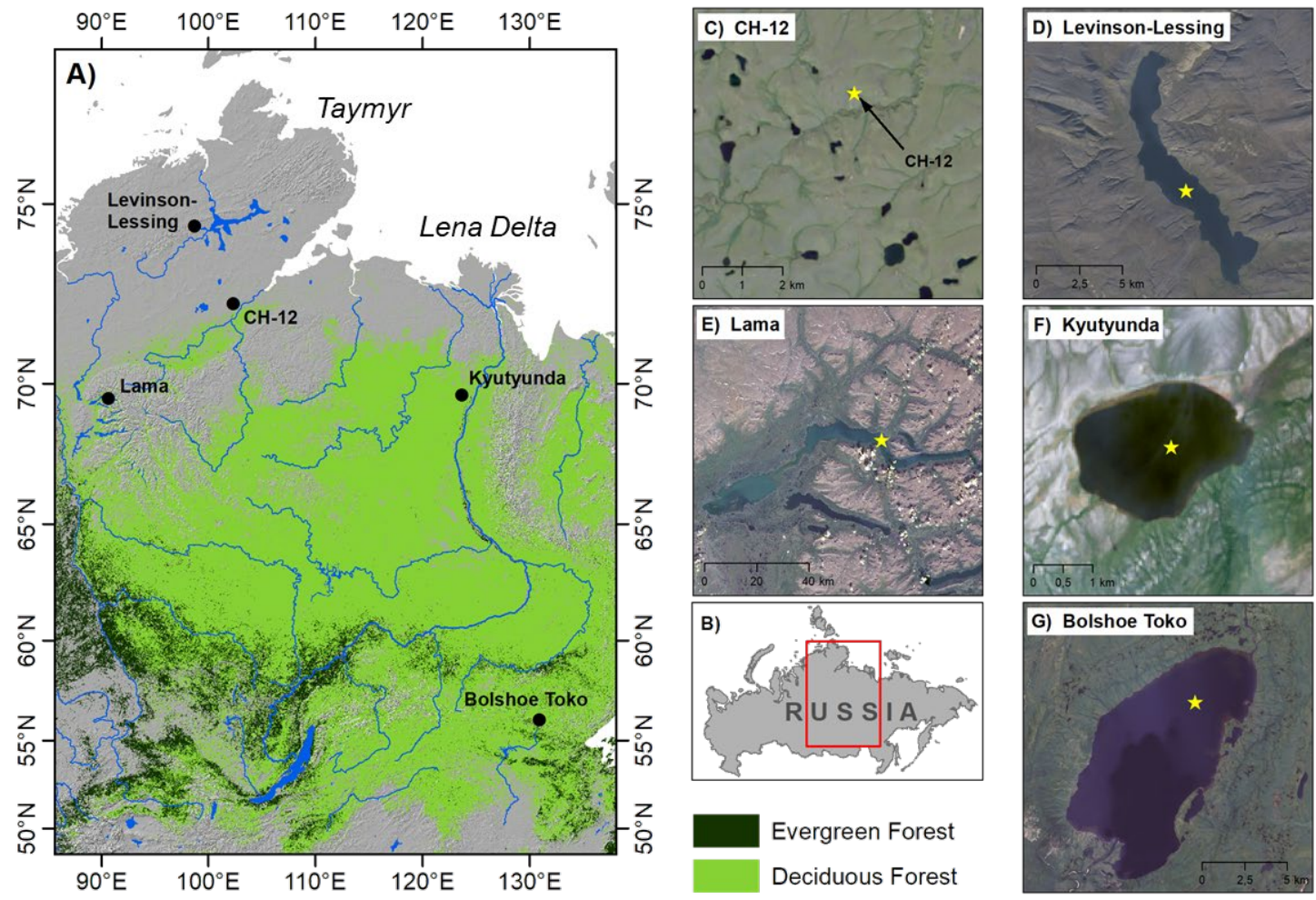

Fig. 1: Map of central Russia showing the location of the study sites. (C) to (G) satellite images of the lakes with their surroundings (core names are indicated in brackets). The locations of the cores are marked with an asterisk.

Lake Levinson Lessing $\left(74.27^{\circ} \mathrm{N}, 98.39^{\circ} \mathrm{E} ; 48 \mathrm{~m}\right.$ a.s.l.) is located in the tundra region of the Taymyr Peninsula. The lake is surrounded by sparse lichen-herb tundra, moss-forb tundra, and dry sedge-forb tundra with dominant Dryas octopetala, Salix polaris, and Cassiope tetragona (Anisimov and Pospelov, 1999). Mean July temperature is $12.5^{\circ} \mathrm{C}$ and mean January temperature $-31.5^{\circ} \mathrm{C}$ (Hatanga weather station; $71.98{ }^{\circ} \mathrm{N}, 102.47^{\circ} \mathrm{E}$; distance to the lake: $289 \mathrm{~km}$ (Russian Institute of Hydrometeorological Information: World Data Center, 2021)). The lake is approximately $15 \mathrm{~km}$ long and has a width of 2.5 $\mathrm{km}$ and a maximum depth of $120 \mathrm{~m}$ (Lebas et al., 2019). In an expedition in April 2017, a $46 \mathrm{~m}$ sediment core (Co1401; Figure 1D) was retrieved from the central part of the lake at a depth of $112 \mathrm{~m}$. According to the chronology, the core covers the last 62 cal ka BP (Scheidt et al., 2021).

Lake $\mathrm{CH} 12\left(72.4^{\circ} \mathrm{N}, 102.29^{\circ} \mathrm{E} ; 60 \mathrm{~m}\right.$ a.s. I.) is located at the tree line on the southern Taymyr Peninsula north of the Putorana Plateau. The current vegetation in the study area is shrub tundra dominated by Sphagnum, Hylocomium, Aulacomnium, Dicranum, and Polytrichum as well as Empetrum nigrum, Betula nana, and Vaccinium oliginosum. Also stands of Larix gmelinii are present (Klemm et al., 2016; Niemeyer et al., 2017). Mean July temperature is $12.5^{\circ} \mathrm{C}$ and the mean January temperature is -31.5 ${ }^{\circ} \mathrm{C}$ (Hatanga weather station; $71.98^{\circ} \mathrm{N}, 102.47^{\circ} \mathrm{E}$; distance to the lake: $60 \mathrm{~km}$ (Russian Institute of Hydrometeorological Information: World Data Center, 2021)). The lake is elliptically shaped with a mean radius of $100 \mathrm{~m}$. The maximum depth of the lake is $14.3 \mathrm{~m}$. A $1.21 \mathrm{~m}$ long sediment core was retrieved in an expedition in 2011 (Figure 1C). The core dates back to 7.1 cal ka BP (Stoof-Leichsenring et al., 2015; Klemm et al., 2016).

Lake Kyutyunda $\left(69.38^{\circ} \mathrm{N}, 123.38^{\circ} \mathrm{E} ; 66 \mathrm{~m}\right.$ a.s.l.) is located in northern Siberia on the central Siberian Plateau in the tundra-taiga transition zone, which is formed of a mosaic of Larix forest and shrub tundra with Poaceae, Dryas, and Saxifraga species. The data from the Kjusjur weather station $(70.68$ ${ }^{\circ} \mathrm{N}, 127.4^{\circ} \mathrm{E}$; distance to the lake: $210 \mathrm{~km}$ (Russian Institute of Hydrometeorological Information: World Data Center, 2021)) give mean July temperatures of $13^{\circ} \mathrm{C}$ and mean January temperatures of 
bioRxiv preprint doi: https://doi.org/10.1101/2021.11.05.465756; this version posted November 5,2021 . The copyright holder for this preprint (which was not certified by peer review) is the author/funder, who has granted bioRxiv a license to display the preprint in perpetuity. It is made available under aCC-BY 4.0 International license.

$-35.3^{\circ} \mathrm{C}$. The lake is roughly circular at $2.2 \mathrm{~km}$ long by $3 \mathrm{~km}$. The deepest part of this lake is $3.5 \mathrm{~m}$. In an expedition in 2010, a $7 \mathrm{~m}$ sediment core (PG2023) dating back to $38.8 \mathrm{cal}$ ka BP was collected (Biskaborn et al., 2016). For the lake Kyutyunda sediment core (Figure 1F) we used an updated version of the age-depth correlation from Biskaborn et al. (2016) with refined correlation between the core segments (Supplementary 1 and 2), based on the IntCal20 calibration curve (Reimer et al., 2020) compiled in the R package bacon (Blaauw and Christen, 2011).

Lake Lama $\left(69.32^{\circ} \mathrm{N}, 90.12^{\circ} \mathrm{E} ; 53 \mathrm{~m}\right.$ a.s.l.) is located on the Putorana Plateau. Low elevations are covered by dense taiga with Picea, Larix, and Betula, shrubs such as Alnus fructicosa, Salix, and Juniperus communis, and dwarf shrubs (Andreev et al., 2004). Modern temperatures vary between a mean of $13.8^{\circ} \mathrm{C}$ in July and $-28.8^{\circ} \mathrm{C}$ in January (Volochanka weather station; $70.97^{\circ} \mathrm{N}, 94.5^{\circ} \mathrm{E}$; distance to the lake: $247 \mathrm{~km}$ (Russian Institute of Hydrometeorological Information: World Data Center, 2021)). This lake covers an area of $318 \mathrm{~km}^{2}$, is $80 \mathrm{~km}$ long and up to $7 \mathrm{~km}$ wide. It has a maximum depth of $254 \mathrm{~m}$. A sediment core with a total length of $18.85 \mathrm{~m}$ (PG1341; Figure 1E) was retrieved from a water depth of $66 \mathrm{~m}$ during an expedition in 1997. The core dates back to $23 \mathrm{cal}$ ka BP. The age-depth model of the sediment core is described in this study (Supplementary 3 and 4). Nineteen sediment samples of Lake Lama were radiocarbon dated with an accelerator mass spectrometer (AMS) MICADAS (MIni CArbon Dating System) at Alfred Wegener Institute Bremerhaven and an age-depth model has been established using the R package bacon (Blaauw and Christen, 2011).

Lake Bolshoe Toko $\left(56.15^{\circ} \mathrm{N}, 130.30^{\circ} \mathrm{E} ; 903 \mathrm{~m}\right.$ a.s.l.) is located on the northern slope of the eastern Stanovoy Mountain Range in southern central Yakutia in an area with deciduous boreal forests formed by Larix cajanderi and L. gmelinii with occurrences of Picea obovata, P. jezoensis, and Pinus sylvestris (Konstantinov 2000). The temperature in the area varies between $34{ }^{\circ} \mathrm{C}$ in July to $-65{ }^{\circ} \mathrm{C}$ in January (Toko weather station; $56.1^{\circ} \mathrm{N}, 131.01^{\circ} \mathrm{E}$; distance to the lake: $44 \mathrm{~km}$ (Konstantinov, 2000)). The lake is $15.4 \mathrm{~km}$ long and $7.5 \mathrm{~km}$ wide, and has a maximum depth of $72.5 \mathrm{~m}$. In an expedition in 2013 (Biskaborn et al., 2019), a $3.8 \mathrm{~m}$ long sediment core (PG2133; Figure 1G) was retrieved from the lake at $26 \mathrm{~m}$ water depth. The core dates back to $33.8 \mathrm{cal}$ ka BP (Courtin et al., 2021).

\section{Materials and Methods}

\subsection{Sampling}

SedaDNA samples were taken from $1 \mathrm{~m}$ long sub-core segments that were cut in half. Subsampling was undertaken in the climate chamber of the Helmholtz Centre Potsdam - German Research Centre for Geosciences (GFZ) at $10^{\circ} \mathrm{C}$. The chamber is located in the cellar of the institute building in which no molecular genetic studies are conducted. Before subsampling, all surfaces in the chamber were cleaned with DNA Exitus Plus ${ }^{\mathrm{TM}}$ (VWR, Germany) and demineralised water. All knives, scalpel holders, and other sampling tools were cleaned according to the recommendations of Champlot et al. (2010) to avoid any contamination with modern DNA and amongst the samples themselves. All materials used for the sampling were taken from the palaeogenetic DNA laboratory at the Alfred Wegener Institute (AWI) in Potsdam where they had been treated to remove DNA.

During the sampling, protective clothing as well as face masks were worn. The surface of the core halves were scraped off twice with sterile scalpel blades and the sample was taken with the help of four knives or two aluminium disks to cut-off the sample and then placed in sterile $8 \mathrm{~mL}$ Sarstedt tubes. All samples were taken under the same conditions. The core from Lake Levinson Lessing was sampled under the same conditions in the laboratories of the Institute of Geology and Mineralogy at the University of Cologne.

The samples were analysed according to their estimated ages, at intervals of about 5 cal kyr, leading to 15 samples from lake Lama, 9 samples from lake Levinson Lessing, 10 samples from lake Kyutyunda and and 8 samples from lake Bolshoe Toko. For lake $\mathrm{CH} 12,28$ samples were taken, representing every 100-250 years. 
bioRxiv preprint doi: https://doi.org/10.1101/2021.11.05.465756; this version posted November 5,2021 . The copyright holder for this preprint (which was not certified by peer review) is the author/funder, who has granted bioRxiv a license to display the preprint in perpetuity. It is made available under aCC-BY 4.0 International license.

\subsection{DNA extraction and amplification}

SedaDNA was extracted using the DNeasy PowerMax Soil DNA Isolation Kit (Qiagen, Germany) according to the manufacturer's instructions. An additional incubation step at $56^{\circ} \mathrm{C}$ in a rotation oven overnight after mixing the samples with the PowerMax beads was included. Proteinase $\mathrm{K}\left(2 \mathrm{mg} \mathrm{mL}^{-1}\right)$ and DTT (5 M) were added before the incubation. The final elution step was conducted using $2 \mathrm{~mL}$ of the solution C6. Each extraction batch was processed on a different day to avoid contamination between the batches. The 70 samples were investigated for both fungi and vegetation. A volume of $0.5 \mathrm{~mL}$ of the $\mathrm{CH} 12$ extracts was purified and at the same time concentrated to $50 \mu \mathrm{L}$ with a GeneJET PCR purification Kit (Thermo Fisher Scientific, Germany). For the other lakes, $1 \mathrm{~mL}$ of the DNA extract was used for the purification. The DNA concentration of concentrated samples was measured with a Qubit Fluorometer (Qubit 4.0 Fluorometer, Thermo Fisher Scientific, USA) and the DNA was diluted to a final concentration of $3 \mathrm{ng} \mathrm{L}^{-1}$. Small aliquots were used to avoid freeze and thaw cycles. DNA extraction blanks were not concentrated, but used purely for subsequent PCR analyses.

For the amplification of fungal DNA, we used the tagged forward primer ITS67 and the tagged reverse primer 5.8S, developed for use on sedimentary DNA (Seeber et al., 2021). The amplified region has a size of approximately $183 \mathrm{bp}$. The use of tagged primers is essential to enable the assignment of the DNA sequences to the original samples after NGS sequencing. For each sample batch, six replicates were conducted independently from each other.

For the reconstruction of the palaeovegetation, we used the chloroplast trnL P6 loop marker region. The tagged primers being used are $\operatorname{trnL} g$ as the forward primer and $\operatorname{trnL} h$ as the reverse primer (Taberlet et al., 2007). For each sample batch, three replicates were conducted independently from each other.

A single PCR reaction contained in total $25 \mu \mathrm{L}$ consisting of $3 \mu \mathrm{L}$ DNA at a concentration of $3 \mathrm{ng}^{-1} \mathrm{~L}^{-1}$, $0.2 \mu \mathrm{M}$ of each primer, 10x HiFi buffer, $2 \mathrm{mM} \mathrm{MgSO} 4,0.1 \mathrm{mM}$ dNTPs (consisting of dGTP, dATP, dCTP, and dTTP), $0.8 \mathrm{mg} \mathrm{mL}^{-1} \mathrm{BSA}$, and 1.25 U Platinum Taq High Fidelity DNA Polymerase (Invitrogen, United States). Each PCR batch also contained $3 \mu \mathrm{L}$ of the corresponding DNA extraction blank and a PCR negative control with $3 \mu \mathrm{L}$ of DEPC-water (deionised and diethylpyrocarbonate treated) instead of the DNA sample. All steps including DNA extraction and PCR set-up were conducted in the palaeogenetic laboratories at AWI Potsdam.

The PCR reaction itself was conducted in the Post-PCR laboratories at AWI Potsdam, which are located in a separate building to avoid contamination of ancient DNA samples with amplified DNA. The reaction for fungal ITS marker amplification was conducted in a thermocycler (Biometra, Germany) following the protocol for voucher samples for the samples from Lake $\mathrm{CH} 12$ (Seeber et al., 2021) while the other samples were amplified using the following protocol: starting with an initial denaturation at $94{ }^{\circ} \mathrm{C}$ for $2 \mathrm{~min}$, followed by 40 cycles of $30 \mathrm{sec}$ denaturation at $94{ }^{\circ} \mathrm{C}, 30 \mathrm{sec}$ annealing at $54{ }^{\circ} \mathrm{C}$, and $30 \mathrm{sec}$ elongation at $72{ }^{\circ} \mathrm{C}$, and a final elongation step of $10 \mathrm{~min}$ at $72{ }^{\circ} \mathrm{C}$. The thermocycler protocol for plant trnL P6 loop amplification followed the protocol of Epp et al. (2018).

The PCR products were checked by gel electrophoresis ( $2 \%$ agarose gels). Only those products showing the expected gene bands were used for purification and subsequent sequencing. Purification was done with the MinElute PCR Purification Kit (Qiagen, Germany) according to the manufacturer's protocol with the final elution in $50 \mu \mathrm{L}$. DNA concentration was measured with a Qubit Fluorometer (Qubit 4.0 Fluorometer, Thermo Fisher Scientific, USA). For sequencing, $40 \mathrm{ng}$ of each purified PCR product were pooled. If no concentration was measurable, the total volume of the purified PCR product was added to the pool. For extraction blanks and PCR non-template controls, $5 \mu \mathrm{L}$ of each PCR product was added. The final pool was purified again with a MinElute PCR Purification Kit (Qiagen, Germany) and adjusted to a final concentration of $33 \mathrm{ng} \mathrm{\mu L}^{-1}$ in a total volume of $30 \mu \mathrm{L}$. In total, three fungal sequencing pools were sent to Fasteris SA sequencing service (Switzerland). The service 
bioRxiv preprint doi: https://doi.org/10.1101/2021.11.05.465756; this version posted November 5,2021 . The copyright holder for this preprint (which was not certified by peer review) is the author/funder, who has granted bioRxiv a license to display the preprint in perpetuity. It is made available under aCC-BY 4.0 International license.

included the library preparation using a specified protocol (Metafast library) and a quality control and sequencing on an Illumina MiSeq platform ( $2 \times 250$ bp, V3 chemistry with an expected output of about 20 million paired-end reads).

We also sequenced two pools for the plant metabarcoding. Pooled purified PCR products of plant trnL P6 loop marker amplifications were sent to Fasteris SA together with other metabarcoding projects from our lab and sequenced on an Illumina NextSeq500 device ( $2 \times 150$ bp, 120 million paired-end reads). In addition, plant trnL P6 loop data from the lake CH12 were used from Epp et al. (2018).

\subsection{Bioinformatic analysis}

The subsequent analysis of the sequencing results was done using the open source OBITools pipeline (Boyer et al., 2016). A detailed description of all filtering steps can be found in Supplement 2. As a first step, illuminapairedend was conducted to pair the ends of the sequences, followed by obigrep to filter out only the joined sequences. Afterwards, ngsfilter was used to demultiplex the file into the unique samples and obiuniq was used to dereplicate the sequence reads. Then, all sequences shorter than 10 bp and with fewer than 10 reads were deleted applying obigrep. For the fungal dataset, the open source sumaclust algorithm (Mercier et al., 2013) was applied to cluster sequences with an identity threshold of 0.97 to generate operational taxonomic units (OTUs). After the filtering steps, ecotag was applied to perform the taxonomic classification of the OTUs against the embl142 (based on the EMBL nucleotide sequence database, release 142 (EMBL142; Kanz et al., 2005) and the UNITE database release for the fungal metabarcoding (Nilsson et al., 2019). The UNITE database is a curated fungus database where the detection of false positive reads might be lower than in the broader EMBL release. Using only the UNITE database for the assignment would potentially preclude identification of certain taxa. Therefore, the final assignment is based on the assignment from the database with the higher identity for each OTU. When both databases produced the same identity, the UNITE database was used for the final taxonomic classification.

For the taxonomic classification of the vegetation dataset, we used the ArctBorBryo database which is based on the quality-checked and curated Arctic and Boreal vascular plant and bryophyte reference libraries (Sønstebø et al., 2010; Willerslev et al., 2014; Soininen et al., 2015).

All databases were built after the following procedure to be applicable for the ecotag algorithm. The sequences of the databases and the NCBI taxonomy files were downloaded and both formatted in the ecoPCR format. Then, ecoPCR was run to simulate an in silico amplification of database sequences with the ITS67 and the 5.8S_fungi primers (allowing 5 mismatches in each primer sequence). The putatively amplified sequences were used as the reference databases and taxonomy information was added.

Resulting OTUs with identity levels equal to or higher than $98 \%$ were used for further analyses of the fungus dataset to keep only well annotated sequences. This is necessary to be certain about the analysis of fungus-plant relationships. For the analysis of the vegetation data, the identity cut-off was at $100 \%$. PCR negative controls and extraction blanks were checked for contamination. All contaminants (non-fungal reads and OTUs occurring in non-template controls and extraction blanks) and aquatic fungi in the samples as well as OTUs with total read counts lower than 10 have been excluded from further analysis. Afterwards, we resampled both datasets to normalise the count data. The vegetation data have been resampled to a base count of 12,489 which resulted in an exclusion of the samples from 9.9 cal ka BP of Lake Kyutyunda and $7 \mathrm{cal} \mathrm{ka} \mathrm{BP} \mathrm{from} \mathrm{CH} 12$ as they had too low counts. The fungus data were resampled to a base count of 5,284 resulting in a sample from $5 \mathrm{cal} k a$ BP from Lake Kyutyunda and a sample from $18.8 \mathrm{cal} \mathrm{ka} \mathrm{BP} \mathrm{from} \mathrm{Lake} \mathrm{Lama} \mathrm{being} \mathrm{excluded} \mathrm{due} \mathrm{to} \mathrm{low}$ read numbers. 
bioRxiv preprint doi: https://doi.org/10.1101/2021.11.05.465756; this version posted November 5,2021 . The copyright holder for this preprint (which was not certified by peer review) is the author/funder, who has granted bioRxiv a license to display the preprint in perpetuity. It is made available under aCC-BY 4.0 International license.

\subsection{Data analyses}

Further filtering of the fungus dataset followed the suggested steps of Schiro et al. (2019). We assigned the identified fungus taxa to functional types according to their role in the ecosystem (Schulze and Mooney, 2012). The mycorrhizal fungi include arbuscular mycorrhizae, ectomycorrhiza, and ericoid mycorrhizae. The other groups are the saprotrophs, parasites, lichens, yeasts, and other symbionts besides mycorrhizae. A large number remained as "unknown" if their role in the ecosystem is not yet well understood. The identified plant taxa were assigned to either woody or herbaceous taxa.

All statistical analyses have been carried out using $R$, version 4.0.3 ( $R$ Core Team, 2020) using percentage data. The taxa were plotted colour-coded after their assigned functional type. Plotting has been done using the tidyverse package and ggplot2 in R (Wickham, 2016). To analyse differences in species diversity amongst the samples and locations, we calculated the alpha diversity using the function specnumber() of each sample from the resampled (rarefied) fungus and plant dataset.

To investigate the relationship between fungi and vegetation, we first assessed whether there is a correlation between fungal OTU richness and plant ASV richness. Second, we related the fungal richness to the most significant vegetation PCA axis scores. Finally, we applied the significant vegetation PCA axes as constraining variables in an RDA performed on fungal compositional data. For that, the scores of the PC axes were merged as a data frame. For each axis, only the taxa which make up most of the separation of the axes were plotted with their names in the final RDA to not overload the RDA with too many taxa. The significance of the vegetation PC axes was identified using PCAsignificance(). We used only 10 samples from Lake $\mathrm{CH} 12$ for the RDA to balance the weight of all lakes in the ordination. All ordination analyses were performed on double square-rooted data.

\section{$\underline{\text { 4. Results }}$}

4.1 Fungi: sedaDNA sequencing results and overall patterns of alpha diversity and taxonomic composition

In total, we obtained 52,213,129 counts in the fungal dataset. After assembling paired-end reads with illuminapairedend, demultiplexing into samples with ngsfilter, and cleaning the sequences with obigrep and obiuniq, we have 25,751 unique sequences with $32,027,606$ counts. Clustering at a similarity threshold of $97 \%$ with sumaclust resulted in 5,411 OTUs. Excluding all OTUs with a lower similarity than $98 \%$ against the reference databases led to 716 remaining OTUs for the embl142 database, whereas the UNITE database returned only 268 different OTUs. After resampling to a base count of 5,284 and the subsequent filtering steps, 118 OTUs remained, covering $95.25 \%$ of the entire dataset, which was investigated. The other OTUs are regarded as "rare" and were not further assessed.

The highest OTU numbers before subsequently filtering taxa were detected in lake CH12 (209 OTUs). This is followed by Bolshoe Toko (146 OTUs) which is surrounded by forest and lake Levinson Lessing (137 OTUs) and lake Lama (135 OTUs). The lowest OTU number was detected for the northern lake Kyutyunda (78 OTUs). The OTU richness of single samples ranges from 3 OTUs (lake Kyutyunda, $30 \mathrm{cal}$ $\mathrm{ka} \mathrm{BP}$ ) to 82 OTUs ( $\mathrm{CH} 12,5.5 \mathrm{cal} \mathrm{ka}$ BP) with a mean of 23.53 OTUs. Samples from the Holocene show a higher richness in comparison to samples from MIS2 and MIS3.

The 10 most dominant taxa, which sum up to $71 \%$ in the entire fungal dataset, are Pseudeurotiaceae (20\%; 30 samples), Mortierella (13\%; 63 samples), Sordariomyceta (11\%; 26 samples), Exophiala (5.8\%; 6 samples), Oidiodendron (5.6\%; 10 samples), Protoventuria (5.5\%; 14 samples), Candida vartiovaarae (3.1\%; 7 samples), Pseudeurotium (2.7\%; 9 samples), Gryganskiella fimbricystis (2.6\%; 32 samples), and Trichosporiella cerebriformis (2.4\%; 11 samples).

The most dominant fungal functional type in the dataset is constituted by the saprotrophs $(40 \% ; 38$ OTUs), while yeasts are present at 10\% (23 OTUs). Parasites (9.05\%; 13 OTUs) and mycorrhizae (4.5\%; 
bioRxiv preprint doi: https:/doi org/10.1101/2021.11.05.465756; this version posted November 5,2021 . The copyright holder for this preprint (which was not certified by peer review) is the author/funder, who has granted bioRxiv a license to display the preprint in perpetuity. It is made available under aCC-BY 4.0 International license.

14 OTUs) are relatively rare. The lowest abundances are the other symbionts (1.07\%; 5 OTUs), lichens (0.2\%; 4 OTUs), and mould (0.2\%; 1 OTU). The fungi with unknown functions comprise $24.2 \%$ ( 21 OTUs) of the dataset.

4.2 Vegetation: sedaDNA sequencing results and overall patterns of alpha diversity and taxonomic composition

In total, we obtained 48,939,032 reads for the vegetation data. Assembling of the paired-end reads, demultiplexing into samples, and cleaning resulted in 152,194 reads. A total of 243 amplicon sequence variants (ASVs) were obtained with a $100 \%$ similarity to references in a curated reference library of arctic and boreal plants (Sonstebo et al., 2010; Willerslev et al., 2014; Soininen et al., 2015).

The comparison of the assigned sequences of the vegetation data between the lakes shows that lake Lama has the highest number of recovered and assigned sequences (163), followed by lake Bolshoe Toko (152) and lake Levinson Lessing (146). Lake CH12 (138) and lake Kyutyunda (133) have the lowest numbers of sequences assigned. The ASV richness of a single sample varies between 9 ( $7 \mathrm{cal} \mathrm{ka}$ BP, $\mathrm{CH} 12$ ) and 112 (35 cal ka BP, Bolshoe Toko).

The most common plant taxa are Salicaceae (37.4\%; 69 samples), Dryas (20.4\%; 69 samples), Larix (5.94\%; 44 samples), Alnus alnobetula (5.88\%; 67 samples), Papaver (3.86\%; 59 samples), Menyanthes trifoliata (3.83\%; 45 samples), Bistorta vivipara (2.72\%, 63 samples), Asteraceae (2.43\%; 66 samples), Betula (1.6\%; 67 samples), and Anemone patens (1.4\%; 18 samples). These ten taxa constitute $85.5 \%$ of the whole dataset.

\section{$\underline{4.3 \text { Site-specific plant-fungus co-variation }}$}

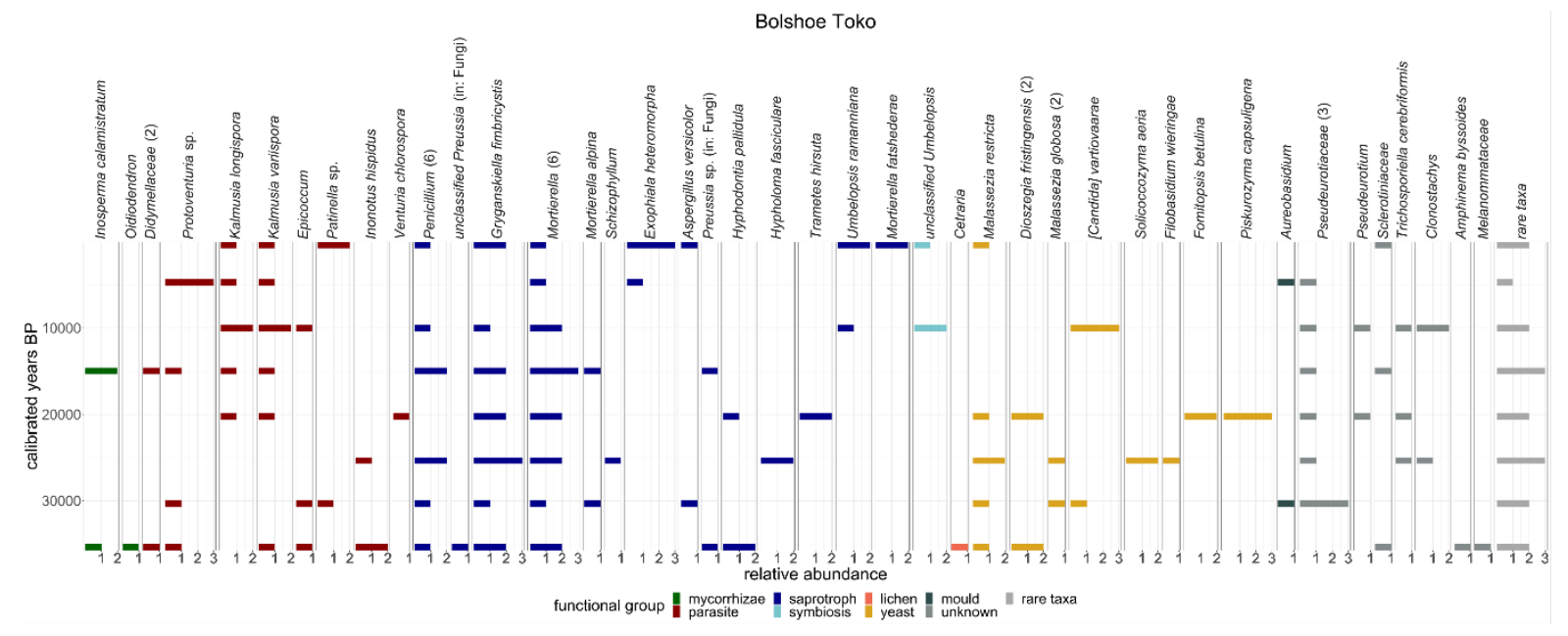



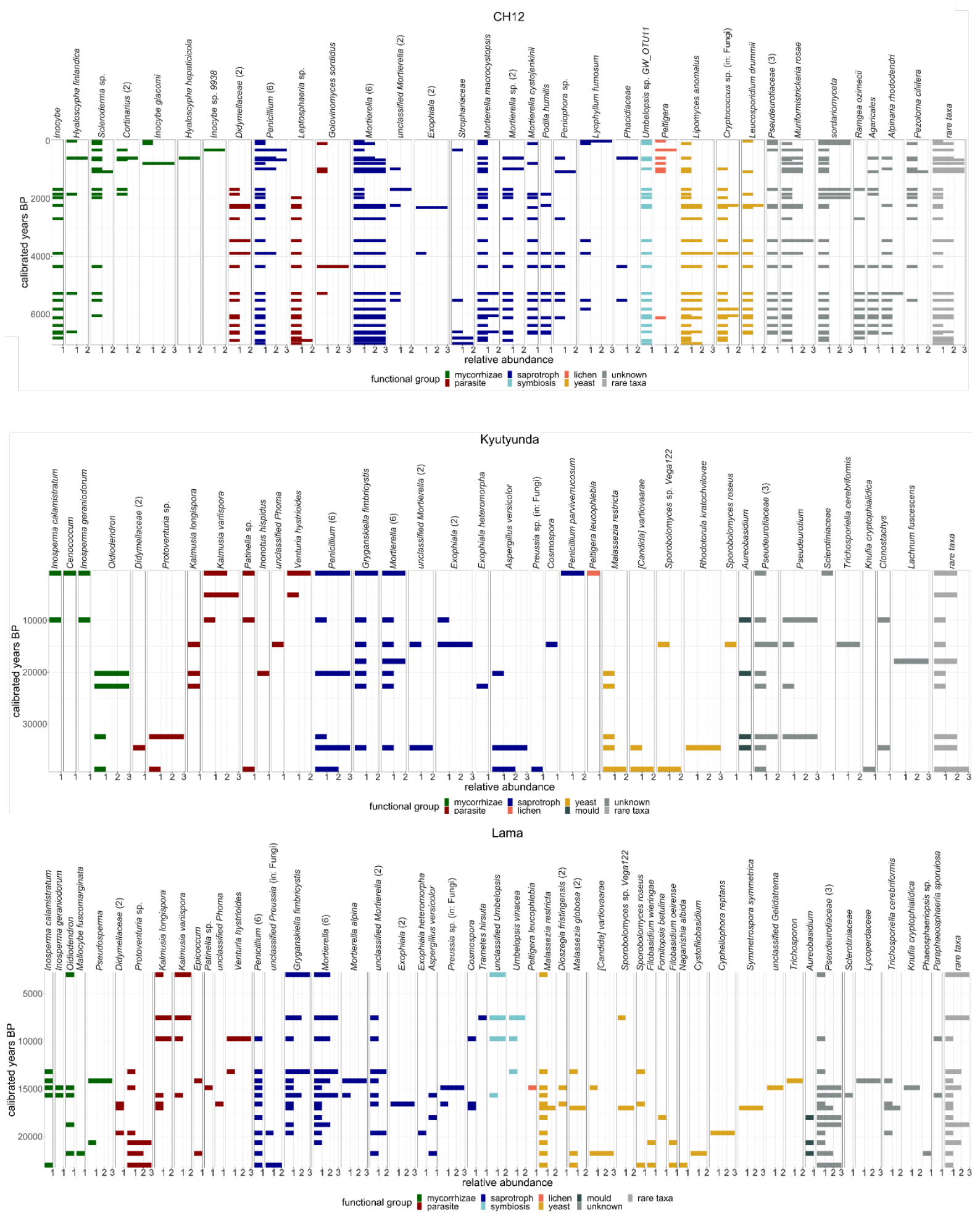


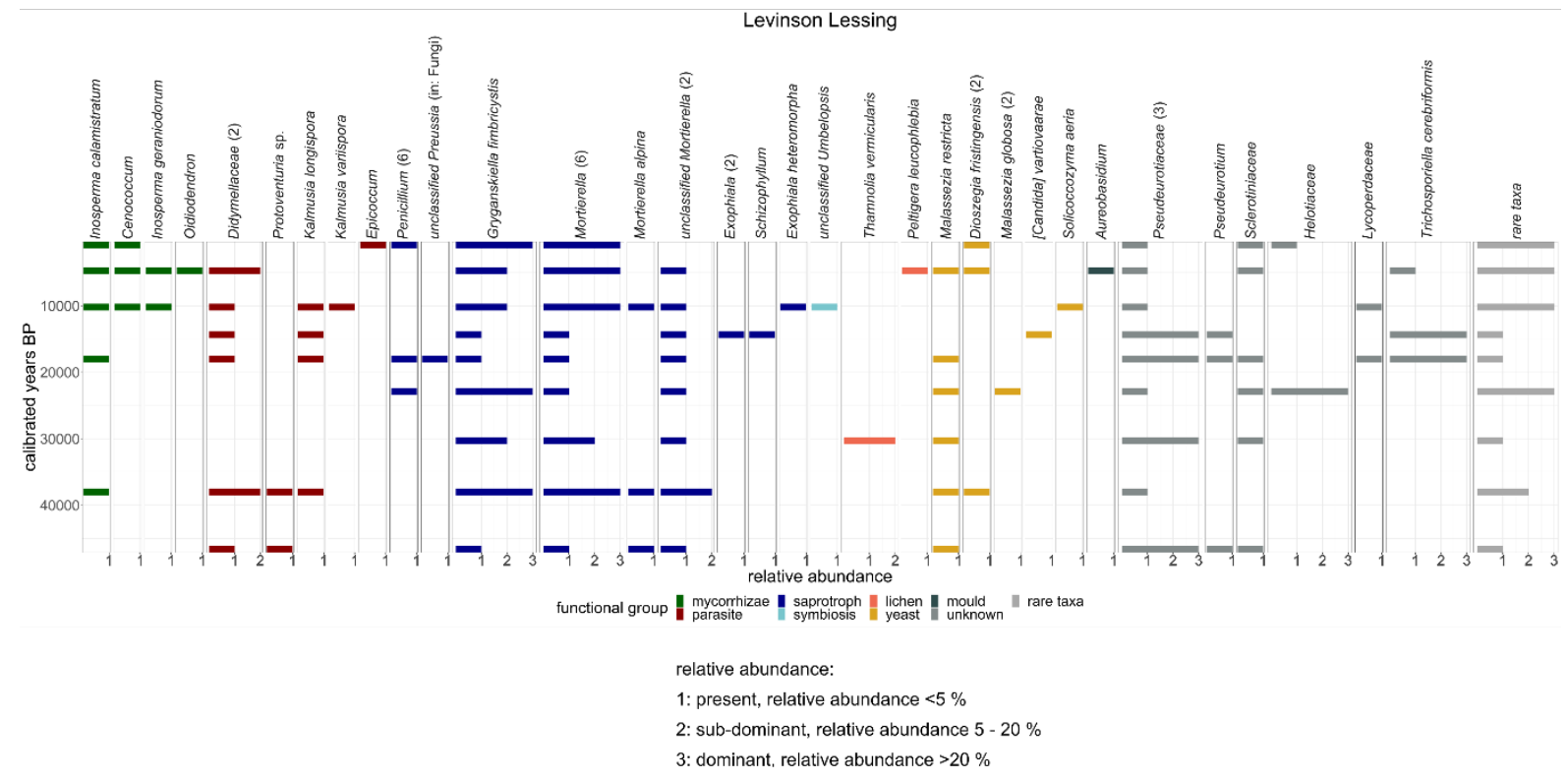

Fig. 2: Site-specific fungus abundance displayed in relative percentages. Fungi of the same functional type are colour-coded. The numbers in brackets give the OTUs detected for the specific taxon.

\subsubsection{Fungus and plant co-variation in Arctic Siberia from MIS3 to the Holocene}

In the Levinson Lessing record (northern Taymyr Peninsula, tundra, 40-0 cal ka BP), the Pseudeurotiaceae as well as Mortierella and Gryganskiella fimbricystis (both saprotrophs) are highly abundant during MIS3 (Figure 2). Around 38 cal ka BP, the Didymellaceae (parasitic fungus family) also occur. At the end of MIS3, Thamnolia vemicularis (lichen) occurs. The most abundant plant taxa at this time are Salicaceae, Dryas, and Papaver. The most abundant fungus taxa in MIS2 are also Pseudeurotiaceae (unknown function) and Mortierella (saprotroph), but Trichosporiella cerebriformis (unknown function) also occurs often. For the plants, the most dominant taxa are Salicaceae and Papaver, followed by Dryas at the end of MIS2 (Figure 3). During the Holocene, Mortierella remains the most frequent fungal taxon but more mycorrhizal OTUs (Inosperma calamistratum, I. geraniodorum, Mallocybe fuscomarginata, Oidiodendron) and parasites (Didymellaceae, Kalmusia variispora) become abundant as well. In the Holocene, there is a drastic decline in Papaver while Alnus alnobetula becomes highly abundant at the beginning of the Holocene. Dryas as well as Salicaceae remain mostly abundant.

The lake $\mathrm{CH} 12$ record (southern Taymyr Peninsula, tundra, 7-0 cal ka BP) only spans the mid to late Holocene. Around $7 \mathrm{cal} \mathrm{ka} \mathrm{BP}$, Inocybe (mycorrhizae) as well as Golovinomyces sordidus and Didymellaceae (parasites) are highly abundant. Mortierella is present throughout the whole record but shows strong declines when mycorrhizae and parasites are abundant around 5 cal ka BP (Figure 2). Until $5.5 \mathrm{cal}$ ka BP, this lake shows high abundances of Alnus alnobetula and Salicaceae. Woody taxa such as Alnus alnobetula, Larix, Betula, and Rhododendron have their highest abundances around 5 cal ka BP (Figure 3). After 5 cal ka BP, an increase in yeast taxa (e.g. Lipomyces anomalus, Cryptococcus) is detected. This coincides with a decline in the aforementioned woody taxa. In this record, the lichen genus Peltigera is abundant in more recent times when the variety of mycorrhizal taxa also increases and Inocybe, Hyaloscypha finlandica, Scleroderma, Cortinarius, Inocybe giacomi, and Hyaloscypha hepaticola occur. Saprotrophic taxa such as Mortierella species, Lyophyllum fumosum, Penicillium, and Exophiala are present throughout the whole record.

The record of lake Lama (northern Siberia, tundra-taiga transition zones, 24-0 cal ka BP) spans MIS2 and the Holocene. The most abundant fungal taxa during MIS2 are Pseudeurotiaceae, Protoventuria 
bioRxiv preprint doi: https://doi.org/10.1101/2021.11.05.465756; this version posted November 5, 2021. The copyright holder for this preprint (which was not certified by peer review) is the author/funder, who has granted bioRxiv a license to display the preprint in perpetuity. It is made available under aCC-BY 4.0 International license.

(parasite), Mortierella (saprotroph), and Cyphellophora reptans (yeast) (Figure 2). Dryas as well as Salicaceae dominate the vegetation. Around the beginning of the Bølling/Allerød (15 cal ka BP), Pseudosperma and Inosperma species (mycorrhizae) become abundant. A little later, Venturia hystrioides and Kalmusia species (all parasites) start to occur. Salicaceae is still the most dominant plant taxon, but Alnus alnobetula, Picea, Betula, and Populus frequently occur after 15 cal ka BP as well. Additionally, a drastic decline in Dryas took place after 15 cal ka BP (Figure 3).

Lake Kyutyunda covers the late MIS3 to the Holocene (northern Siberia, tundra-taiga transition zones, 38.8-0 cal ka BP). The most dominant fungal taxa during the late MIS3 are Oidiodendron (mycorrhizae), Pseudeurotium (unknown function), and Penicillium (saprotroph) (Figure 2). During this time, Salicaceae and Asteraceae are the most abundant plant taxa but Alnus alnobetula also occurs occasionally (Figure 3). Oidiodendron is mainly present at the end of MIS3. Shortly after, a large increase in Betula is detectable. In MIS2, the fungal taxa Oidiodendron and Penicillium are still highly prevalent and the taxon Lachnum fuscescens (unknown function) becomes common (Figure 2). Salicaceae remain the most dominant plant taxon and Betula starts to occur more frequently. High abundance of Dryas as well as the first instances of Alnus alnobetula are detectable in the late MIS2 (Figure 3). During the Holocene, Pseudeurotium (unknown function) and Kalmusia variispora (parasite) became the most abundant fungal taxa. Salicaceae maintained its broad distribution while other woody taxa such as Alnus alnobetula and Rhododendron increased in their abundances.

The samples from Bolshoe Toko also span the late MIS3 to the Holocene (central Yakutia, taiga, 35-0 cal ka BP). During the late MIS3, the Pseudeurotiaceae are the most abundant fungal family in this lake but parasitic species (e.g. Kalmusia species, Inonotus hispidus) and saprotrophs (e.g. Mortierella, Grykanskiella fimbricystis) also occur (Figure 2). At this time, Salicaceae has the highest abundance amongst the plants with Dryas occurring frequently. Alnus alnobetula and Betula are also present but at low abundance (Figure 3). In MIS2, Gryganskiella fimbricystis and Mortierella are highly abundant fungi and a few yeast taxa (e.g. Dioszegia fristringensis, Piskurozyma capsuligena) start to occur. In the late MIS2, Inosperma calamistratum (mycorrhizae) also occurs. The vegetation is still dominated by Salicaceae until the end of MIS2 with scarce abundances of Alnus alnobetula and Betula. In the Holocene, Protoventuria (parasite) is the most abundant fungal taxon but also Kalmusia species (parasite), Exophiala heteromorpha (saprotroph), and Candida vartiovaarea (yeast) are commonly found. A large increase in more diverse woody taxa is detected with more occurrences of Salicaceae as well as Alnus alnobetula, Betula, Larix, and Populus. 
bioRxiv preprint doi: https://doi.org/10.1101/2021.11.05.465756; this version posted November 5, 2021. The copyright holder for this preprint (which was not certified by peer review) is the author/funder, who has granted bioRxiv a license to display the preprint in perpetuity. It is made available under aCC-BY 4.0 International license.
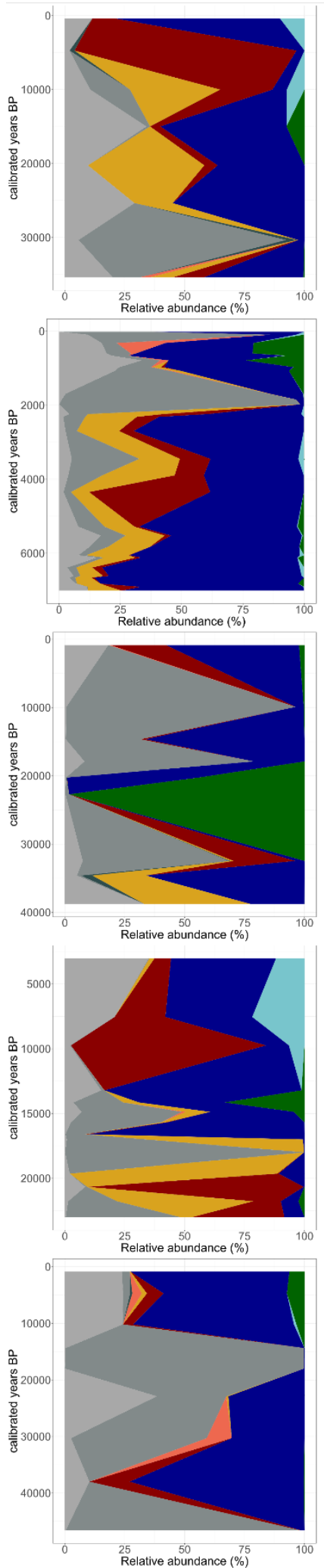
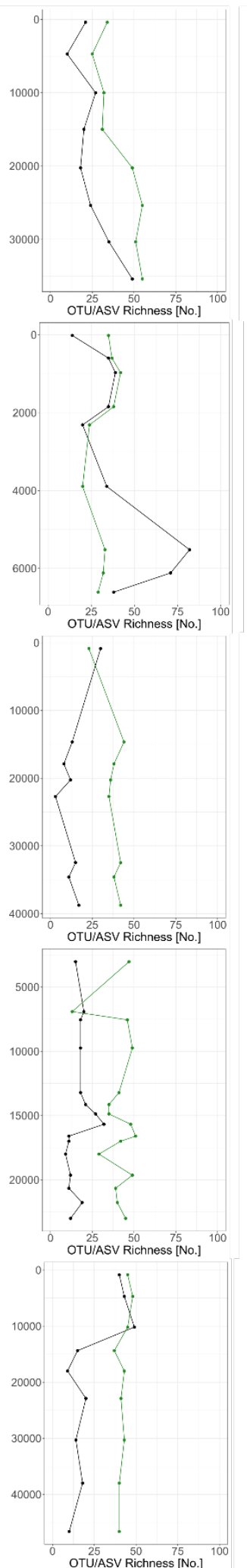
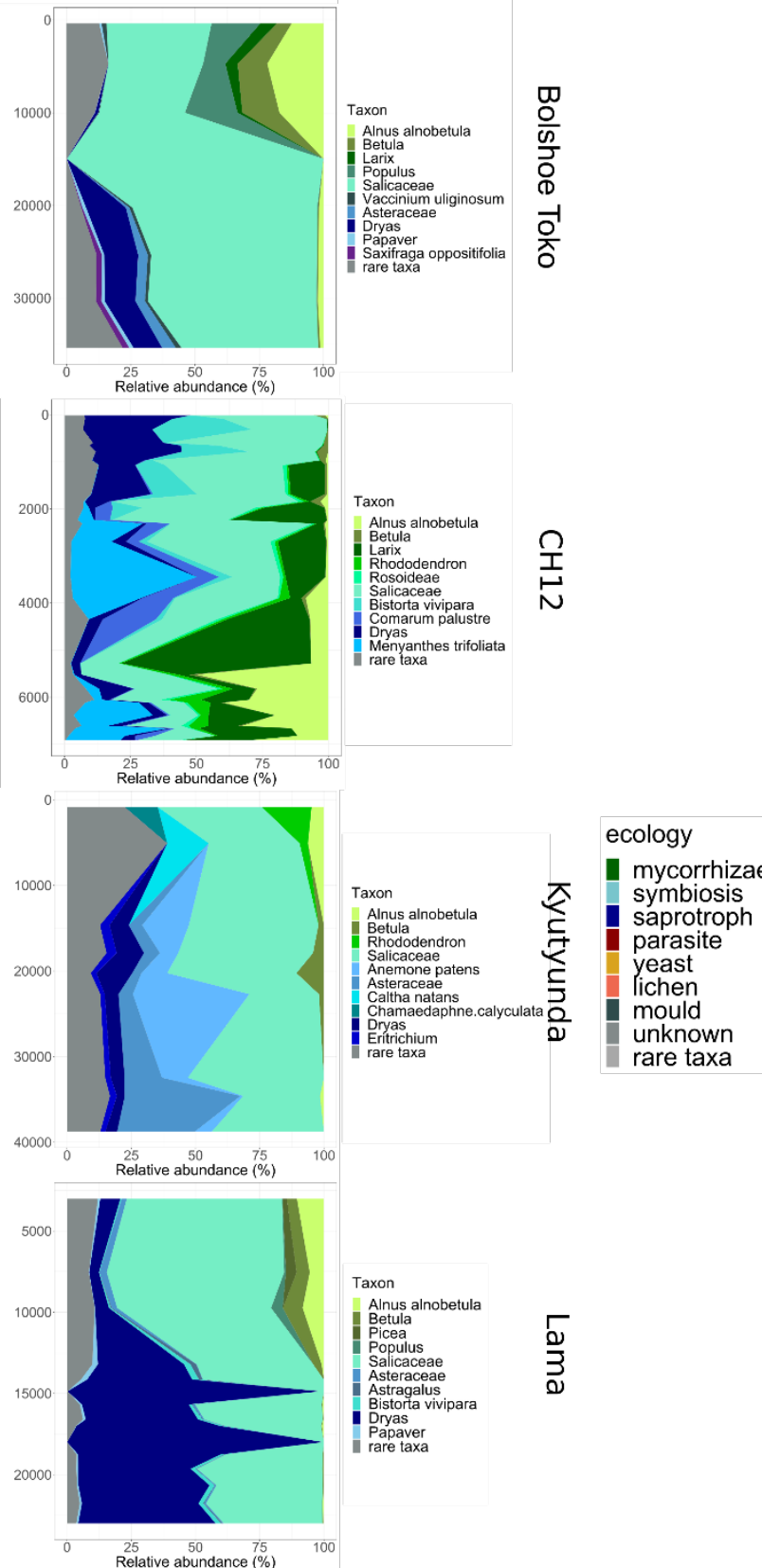

$\frac{\sigma_{0}^{2}}{3}$

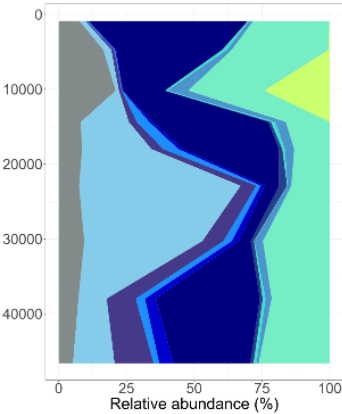

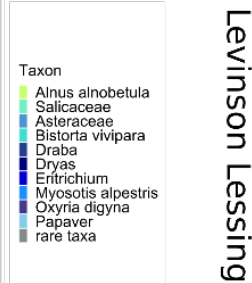

Fig. 3: Fungal functional types in relation to fungal OTU richness and dominant plant taxa. Left column: distribution of fungal functional types for each lake. Middle column: fungal OTU richness of each lake (total OTU numbers), with the black line representing the fungal taxa while the green line marks the vegetation ASVs as comparison. Right column: ten most dominant plant taxa of each lake. 
bioRxiv preprint doi: https://doi.org/10.1101/2021.11.05.465756; this version posted November 5, 2021. The copyright holder for this preprint (which was not certified by peer review) is the author/funder, who has granted bioRxiv a license to display the preprint in perpetuity. It is made available under aCC-BY 4.0 International license.

\subsubsection{Quantitative relationships between fungi and plant richness and composition}

Taking all records together, we found only a weak borderline-significant correlation between fungi OTU and plant ASV richness ( $r$ 0.2394, $p$-value 0.098). Fungal richness is positively correlated to the samples scores of the first plant PCA axis (PC1: $r 0.3863, p$-value 0.006 ) and negatively correlated to the sample scores of the second plant PCA axis (PC2: $r-0.41, p$-value 0.003). The first axis reflects the differences between samples characterised by woody taxa including Larix and Alnus alnobetula and typical tundra taxa. On the second axis, we detected herbaceous plant taxa such as Anemone patens and Thymus positively correlating alongside other taxa preferring wetter habitats. Taxa such as Oxyria digina and Dryas, which are associated with rather dry sites, show a negative correlation.

Sample scores of plant PCA axes 1-5 explain 20\% of fungi composition ( $p 0.001)$ as revealed by RDA (Figure 4). The PCA of the vegetation composition can be found in Supplementary 3. Woody taxa such as Alnus alnobetula, Larix, and Rhododendron appear in the upper right quadrant of the RDA plot together with the fungal taxa Mortierella_003 (saprotroph), Cryptococcus (yeast), and Muriformistrickeria rosae (unknown function) (Figure 3) and samples from $\mathrm{CH} 12$ aged 5.5 and $1.8 \mathrm{cal}$ ka BP. The RDA also shows that parasitic fungi, such as Didymellaceae, and yeast, such as Lipomyces anomalus and Cryptococcus, tend to occur in the presence of woody taxa. Lichens occur predominantly in samples of Holocene age. Papaver and Dryas together with the fungal taxa Pseudeurotiaceae, Grykanskiella fimbricystis (saprotroph), and Mortierella (saprotroph) species occur in the lower left quadrant together with all samples from Levinson Lessing. Populus and Ranunculus in the upper left quadrant appear together with Lipomyces anomalus (yeast), Cryptococcus (yeast), and Mortierella (saprotroph). The samples here mostly originate from Bolshoe Toko although there are also some from lake Lama (around the Bølling/Allerød period) and lake Kyutyunda (Holocene). The samples from the Holocene all occur in the upper half of the RDA where the woody plant taxa are found and a broader fungal species richness is detected. In general, Lake $\mathrm{CH} 12$ shows a unique fungal composition in comparison to the other lakes. The samples can be found in the right quadrants of the RDA while the samples of the other lakes are located in the left quadrants or centred (Figure 4). 


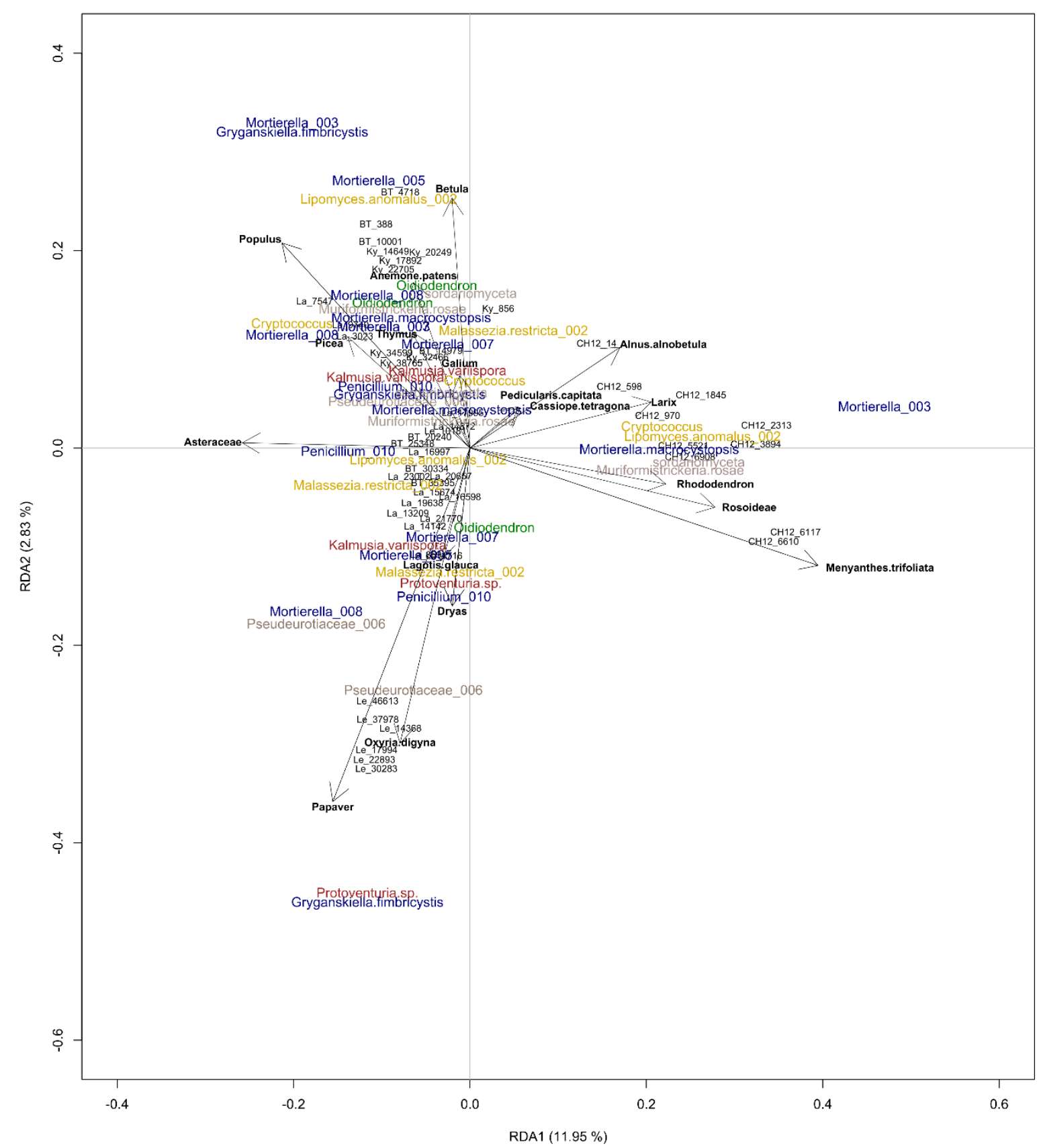

Fig. 4: Fungal and plant co-variation displayed in a redundancy analysis (RDA). The most relevant principal component axes of the vegetation were determined, the scores extracted and then integrated into the RDA. The fungal taxa are displayed colour-coded according to their functional group (see Figures 2 and 3 ). The plant taxa are marked with black arrows. The numbers after the taxa names indicate the specific OTU. The sample names are shortened with the lake name (BT= Bolshoe Toko, Ky = Kyutyunda, La = Lama, Le = Levinson Lessing) and the calibrated year BP. The vegetation explains $20 \%$ of the fungus distribution. 
bioRxiv preprint doi: https://doi.org/10.1101/2021.11.05.465756; this version posted November 5,2021 . The copyright holder for this preprint (which was not certified by peer review) is the author/funder, who has granted bioRxiv a license to display the preprint in perpetuity. It is made available under aCC-BY 4.0 International license.

\section{Discussion}

\subsection{Fungi richness along vegetation gradients in Siberia}

Using sedimentary DNA metabarcoding of 70 samples from five lake sediment cores from Siberian tundra and forested sites, we tracked a high fungal richness (706 OTUs). So far, Siberia has not been targeted by high-throughput sequencing analyses focusing on fungi diversity over a spatial gradient despite hundreds of these studies being available worldwide (Baldrian et al., 2021). In our study, we used OTU clusters instead of observed species, which could have led to an under- or overestimation of richness (Frøslev et al., 2017). Underestimation of richness may originate from missing reference material of arctic and alpine taxa in databases including species that have not yet been described (Goodwin et al., 2016; Quince et al., 2009). A species assessment from the western Ural Mountains, covering a similar environmental setting, yielded a richness of a similar order of magnitude, that is of 376 different fungal species (Palamarchuk and Kirillov, 2019). This supports the conclusion of Seeber et al. (2021) that the marker is suitable to assess fungal diversity even on a very long time-scale. For comparison, higher OTU richness (1125 OTUs in 55 samples) was obtained by Talas et al. (2021) in their study of a Holocene lake sediment core from eastern Latvia. The higher overall diversity is explained by the inclusion and detection of aquatic fungi (about $23 \%$ of their taxa, terrestrial about 40\%), which are mostly lacking in our data. In addition, Talas et al. (2021) did not remove very short reads and included reads with fewer counts ( 4 instead of 10 in our study).

Lake Bolshoe Toko (146 OTUs) and lake Lama (135 OTUs) from forested areas show overall higher OTU richness in comparison to lake Kyutyunda (78 OTUs) from the northern tundra (Figure 3). A relationship between fungal species richness and vegetation composition is shown by many studies (e.g. Tedersoo et al., 2013; Geml et al., 2017), however studies from the Siberian treeline ecotone are hitherto lacking. Our study agrees with the finding that ectomycorrhizal fungal richness is highest with forest cover (Geml et al., 2017). The spatial fungal richness gradient is confirmed by the temporal relationship - we observed a co-occurrence of high fungal richness and woody vegetation (as inferred from sedaDNA using the trnL P6 loop marker). For example, the lake Levinson Lessing record shows a large increase in the fungal OTU richness and woody taxa dominance during the warm Holocene compared with the (late) Glacial period. In contrast, experimental warming did not result in higher fungal diversity (Geml et al., 2015; Mundra et al., 2016). The lake Lielais Svētinu sediment study from the Holocene by Talas et al. (2021) showed high richness as well as community turnover with increases in plankton parasitic species and mycorrhiza after $4 \mathrm{cal}$ ka BP, suggesting that those fungi that are more specific with their hosts or substrates - such as ectomycorrhizae - are more susceptible to ecosystem changes than taxa with wide preferences. In our data, lake $\mathrm{CH} 12$ shows higher OTU richness than the other lakes, even when a similar number of samples is considered, which supports the hypothesis that fungal communities from the warmer Holocene might be more species rich. Potentially, warming-induced vegetation responses rather than direct warming shape the diversity in fungal communities. This suggests that future treeline shifts northwards will bring along a broadening diversity of fungi species.

A study from sub-arctic Canada observed an overall higher fungal diversity on moss tissue compared with conifer litter (Matsuoka et al., 2021) indicating that in addition to the overall vegetation gradient, further biotic (He et al., 2017) and abiotic (Genevieve et al., 2019) factors including soil condition and wetness are important (Geml et al., 2016). Metabarcoding studies on arctic tundra communities reveal that even for each specific tundra type, the communities of the associated fungi are unique (Wallenstein et al., 2007; Geml et al., 2021). This might explain the overall highest fungal OTU richness originating from lake $\mathrm{CH} 12$ (a dry forest tundra site), while lake Kyutyunda (a wet southern tundra site) shows a rather low richness. Furthermore, our analysis shows a negative correlation between fungal richness and the second vegetation PC axis, covering a wetness gradient from species related to drier areas (high PC scores) to species rather related to wetter areas. 
bioRxiv preprint doi: https://doi.org/10.1101/2021.11.05.465756; this version posted November 5,2021 . The copyright holder for this preprint (which was not certified by peer review) is the author/funder, who has granted bioRxiv a license to display the preprint in perpetuity. It is made available under aCC-BY 4.0 International license.

A study on multiple sites of the Tibetan plateau showed that fungal richness is positively correlated with plant richness (Yang et al., 2017). Interestingly, we find only a weak positive correlation between fungal richness and plant richness, which might originate from a complex relationship between plant richness and vegetation composition. Also, we assessed plant ASVs and fungal OTUs which makes a direct comparison difficult. Incomplete databases for arctic fungi might also lead to underestimation of taxa. It is known that at the broad scale, plant richness decreases with latitude (Kerkhoff et al., 2014). However, a study of modern vegetation from Kamchatka, Russian Far East, reports highest plant species richness in alpine tundra and snowbed communities (Doležal et al., 2013). A recent sedaDNA study from the treeline zone in Chukotka (Russian Far East) and from Bolshoe Toko (which is also part of the present study) showed that terrestrial plant richness was particularly high in the late Pleistocene in steppe-tundra areas and lower in the forested Holocene (Huang et al., 2020; Courtin et al., 2021). This indicates that a high correlation between fungus and plant alpha diversity cannot be expected.

\subsection{Changes in fungal functional groups related to vegetation transition}

\subsubsection{Mycorrhiza}

Most mycorrhizal taxa detected and most reads obtained all over the analysed cores are from the families Cortinariaceae and Inocybaceae and some from Myxotrichaceae and Hyaloscyphaceae (Figure 2). This is in accordance with previous fungal metabarcoding studies (Nilsson et al., 2005; McGuire et al., 2013; Botnen et al., 2014). We observed Inocybe (including the subgenus Inosperma (Matheny et al., 2020)) and Cortinarius, both of which are known from high latitudes (Timling et al., 2012). They represent ectomycorrhiza associates of arctic tundra and shrubs including Salix and Dryas integrifolia (Ryberg et al., 2009; Botnen et al., 2014), which are common taxa in our plant metabarcoding dataset. It also supports previous studies from boreal forests (McGuire et al., 2013), including a study from the Russian Far East which detected Cortinarius, in addition to Lactarius and Russula, as important ectomycorrhiza of Larix gmelinii in this region (Miyamoto et al., 2021). In addition to Pinaceae, Cortinarius associates with shrubs of Salicaceae and Rosaceae as well as herbaceous Cyperaceae (Garnica et al., 2005), which are common families in our plant metabarcoding dataset. Nevertheless, mycorrhizal fungi in the treeline area are highly dependent on the specific locality itself and its soil properties such as $\mathrm{pH}$, nutrient availability, and C: $\mathrm{N}$ ratio (Toljander et al., 2006).

It has been reported earlier that, as a consequence of the Last Glacial, vegetation species richness decreased as well as arbuscular mycorrhizal taxa while ectomycorrhizal and non-mycorrhizal fungi increased (Zobel et al., 2018). This resulted in changes in the mutualist trait structure after the Last Glacial Maximum (LGM), leading to an increase of ectomycorrhiza associated with woody taxa and a decrease in arbuscular mycorrhiza forbs. Therefore, mycorrhizal associations are important factors when predicting the species responses to changing environmental conditions (Zobel et al., 2018). We also observe a generally increasing fungal richness in the Holocene samples (Figure 3). Long-term changes in the diversity of fungal communities are highly dependent on soil age, and richness increases with growing soil age (Cutler et al., 2014). This strengthens our observations and underlines the suitability of sedaDNA fungal metabarcoding studies for appropriate ecosystem reconstructions.

Interestingly, we observed highest values of Pinaceae only after the presence of mycorrhizal taxa (Cortinariaceae and Inocybaceae; e.g. Cortinarius and Inosperma calamistratum) (Figures 2 and 3), although this might be by chance because of our low sample numbers. If no mycorrhizal fungi are present in a habitat, growth of Pinaceae individuals is slowed down or establishment is inhibited as nutrient uptake is not possible for non-mycorrhizal roots (Marschner and Dell 1994). Studies from Japan (Ishida et al., 2007) and temperate areas in the Himalaya (Pande et al., 2004) revealed Cortinariaceae as one of the main ectomycorrhizal associates of Pinaceae, which strengthens the preciseness of our dataset and its possibility to correctly recover fungal-plant covariation over a long 
bioRxiv preprint doi: https://doi.org/10.1101/2021.11.05.465756; this version posted November 5, 2021. The copyright holder for this preprint (which was not certified by peer review) is the author/funder, who has granted bioRxiv a license to display the preprint in perpetuity. It is made available under aCC-BY 4.0 International license.

time scale. Our analysis also highlights the longevity of the dependency of the Pinaceae family on these particular fungi.

\subsubsection{Saprotrophs}

We found Mortierella, Penicillium, and Exophiala species as the main biomass-decaying taxa (Figure 2). These are common soil fungi also in high-latitude ecosystems (Treseder et al., 2007; Allison et al., 2009). Mortierella and Penicillium, two of the most common taxa in our dataset, are reported as some of the main soil fungi in arctic tundra soils (Kurek et al., 2007; Zhang et al., 2016) due to their cold tolerance. Mortierella was also found as an associate of Vaccinium uliginosum, Betula nana, Salix glauca, Empetrum nigrum, and Cassiope tetragona (Voříšková et al., 2019), which are typical taxa in our metabarcoding study. Rhizosphere samples from Larix sibirica and Betula pendula from Krasnoyarsk, Siberia revealed Penicillium as one of the main constituents (Boyandin et al., 2012). On the other hand, we did not find typical saprotrophs known from central Siberian forests unaffected by permafrost such as Fomitopsis pinicola. Hymenochaete cruenta, Rhodofomes cajanderi, and Trichaptum abietinum (Park et al., 2020). Nevertheless, Larix forests growing on permafrost show a broad host spectrum towards saprotrophic species (Leski and Rudawska, 2012) as a response to changing environment, for example after wildfires (Miyamoto et al., 2021), which favours their survival and explains why different studies recover other associated taxa.

Saprotrophs are generally highly abundant throughout all records. The significant decrease in saprotrophic fungi around $10 \mathrm{cal}$ ka BP for all lakes (Figures 2 and 3) demonstrates that the drastic climate change during the Pleistocene/Holocene transition (Biskaborn et al., 2016; 2021) also affected soil communities. This finding from natural past warming agrees with results from experimental warming studies, indicating that relative saprotroph abundance declines with warming, while the abundance of mycorrhizal fungi and lichen increases (Deslippe et al., 2012; Geml et al., 2015; Mundra et al., 2016).

\section{$\underline{5.2 .3 \text { Parasites }}$}

The most abundant parasitic species from our dataset are Protoventuria, Kalmusia variispora, Kalmusia longispora, and Didymellaceae which co-occur with Salicaceae, Larix, and Alnus alnobetula (Figures 2 and 3). Protoventuria species, for example, penetrate leaves and show up as distinct spots on the plant leaf (Carris and Poole, 1993). In shrubby tundra in Greenland with Salix occurrences, Venturia species are amongst the highest abundant fungi (Voříšková et al., 2019), indicating a strong covariation between this fungus and Salix. To date, plant-parasite interplay in relation to climate change is not fully understood (Burdon and Zhan, 2020) but it is assumed that parasitic fungal species are more specific in their hosts than, for example, mycorrhizal taxa are (Põlme et al., 2018).

Generally, we detected parasitic OTUs mostly in sediment samples from the warm Holocene (Figure 2). This confirms early findings that experimental warming leads to an increase in parasitic and virulent fungi (Geml et al., 2015) along with woody taxa expansion. Interestingly, we can observe a drastic decline in Salicaceae after the high Protoventuria abundance around 20 cal ka BP (Figures 2 and 3), which supports previously recovered high fungal parasite abundances in permafrost during the last ice age (Lydolph et al., 2005). Fungi from the family Venturiaceae have been assigned to Salicaceae as pathogenic species in northern latitudes (Hosseini-Nasabnia et al., 2016), while Kalmusia was detected in Alnus forests in Lithuania (Iznova and Rukšèniené, 2012). Didymellaceae is co-occurring with a broad range of host plants such as Larix decidua (Chen et al., 2017). In our data, the RDA reveals that Kalmusia species preferentially occur in forested areas alongside saprotrophic and mycorrhizal species (Figure 4). This supports the value of our data and the feasibility of co-occurrence analysis in sedaDNA studies. 
bioRxiv preprint doi: https://doi.org/10.1101/2021.11.05.465756; this version posted November 5,2021 . The copyright holder for this preprint (which was not certified by peer review) is the author/funder, who has granted bioRxiv a license to display the preprint in perpetuity. It is made available under aCC-BY 4.0 International license.

\subsubsection{Lichens}

Our analyses are among the few palaeo-ecological studies that have detected lichens (Figure 2). They are commonly lacking in fossil records (Taylor and Osborn, 1996) despite being an important component of boreal forest and tundra biomass (Asplund and Wardle, 2017; Shevtsova et al., 2020). However, we could only detect very few lichen reads, belonging to 48 OTUs (less than $1 \%$ of the whole dataset). Generally, environmental metabarcoding has been assessed as a valuable tool to investigate modern lichen communities (Fernández-Mendoza et al., 2017) and yielded higher OTU richness than the analysis of voucher specimens from the same region (Wright et al., 2019). Lichen DNA has been reported to drastically degrade after a few hundred years (Kistenich et al., 2019). This means that lichens might be harder to recover from broad fungal palaeo-metabarcoding studies than other functional groups. A specific set of markers established for the amplification of lichen DNA targeting not only the fungus part of the lichen but also the phyco- and cyanobionts could be an asset to improve the taxonomic resolution as well as to trace diversity.

In total, the recovered lichen OTUs belong to 16 families. The families with the highest OTU numbers are Peltigeraceae and Parmeliaceae and the most abundant genera are Thamnolia, Peltigera, and Cetraria with all of them being common elements in northern Siberian communities (Zhurbenko and Yakovchenko, 2014) and permafrost (Lydolph et al., 2005). Thamnolia species often occur in arctic tundra communities (Sheard, 1977) and are of low specificity concerning their photobiont as they associate with various Trebouxia species (Nelsen and Gargas, 2009). Peltigera preferentially grows in temperate regions on soils and among mosses over rocks, but can also be found on tree trunks (Nash 2002) and in boreal forests (Asplund and Wardle, 2015), explaining their abundance in the more forested Holocene in our records from $\mathrm{CH} 12$ (Figure 2).

Interestingly, almost all lichens are recorded from sediments of warm periods with well-developed vegetation, namely the late MIS3 and the Holocene. This is to some extent unexpected, as lichens are a prominent feature of arctic landscapes and short-term experimental warming in the Canadian arctic led to a decline in lichen abundance (Fraser et al. 2014). For Siberia, lichens have been recovered along a broad latitude gradient with high diversity and biomass (Safronova and Yurkovsksya, 2019). Lichens have been discovered to possess a cooling effect when growing on permafrost, giving them great importance when considering thawing effects on permafrost (Porada et al., 2016). The implication of a potentially reduced or missing lichen cover during the glacial might be of relevance for past permafrost soil carbon dynamics. Lichens are reported to tolerate high percentages of $\mathrm{CO}_{2}$ (Badger et al., 1993), but studies about the impact of low $\mathrm{CO}_{2}$ supply are not available. Possibly, lichens suffer more than other fungi from reduced atmospheric $\mathrm{CO}_{2}$ content as they also have to supply their algal or cyanobacterial symbiont.

The distribution of lichens also has an impact on the occurrence of animals such as Moschus moschiferus, which preferentially settle in lichen-rich habitats for their food supply (Slaght et al., 2019). Increased lichen coverage during the Holocene may have supported the compositional turnover in the megaherbivore fauna. Reindeer mostly feed on lichen but changing environmental conditions will probably impact their distribution as well as their diet to include less lichen (Drucker et al., 2011) or seasonal variations in their diet (Bocherens et al., 2015), which would give them a higher survival advantage. Changing fungus communities will thus not only impact the boreal forest taxa, but also its fauna and general soil properties.

\section{$\underline{5.2 .5 \text { Yeast }}$}

The most abundant yeast taxa from our dataset are [Candida] vartiovaarae, Malassezia restricta, Cyphellophora reptans, Cryptococcus, and Lipomyces anomalus (Figure 2). These taxa are widely distributed in soils in Siberia (Polyakova and Chernov, 2001). A study from Germany showed [Candida] vartiovaarae to be broadly present in forest as well as in grassland soils (Yurkov et al., 2012), while 
bioRxiv preprint doi: https://doi.org/10.1101/2021.11.05.465756; this version posted November 5,2021 . The copyright holder for this preprint (which was not certified by peer review) is the author/funder, who has granted bioRxiv a license to display the preprint in perpetuity. It is made available under aCC-BY 4.0 International license.

Cryptococcus is associated with peatland (Thormann, 2006) and boreal swamps (Kachalkin and Yurkov, 2012). A correlation between Malassezia species and soil nematodes in central European forests has been found, suggesting that the nematodes act as vectors for the small fungi (Renker et al., 2003). To investigate these zoophilic relationships for the palaeoenvironment, further metabarcoding data on small soil organisms could be an asset.

Whenever yeasts are highly abundant in the records, mycorrhizal taxa decrease (Figures 2 and 3) (and vice-versa making them antagonists in their response to warming and further environmental changes). In our dataset, yeasts were present preferentially in colder time periods like the LGM. Most yeast species can show an adaptive response when temperatures drop to maintain their survival (Kandror et al., 2004). Aside, experimental warming studies underline our finding that yeast taxa decline with rising temperatures (Treseder et al., 2016). This indicates that some yeast species will lose their habitats with ongoing warming, resulting in a major feedback on the ecosystem, potentially leading to ecosystem turnover.

From our data, it is not possible to determine the role of yeast in the soil. Soil yeast can serve both as biotoxins (Santos et al., 2004; Compant et al. 2005) or growth promoters for plants (Nassar et al., 2005; El-Tarabily and Sivasithamparam, 2006). It is likely that in Siberian soils, yeasts either function as plant parasites (Hernández-Fernández et al., 2021) or as biodegraders, as after a period of high yeast abundance, we detect a decrease in woody taxa. A better understanding of modern mutualistic and parasitic interactions in Siberian tundra and taiga soils will help to solve this research gap.

\subsection{Implications of our results for ecosystem functioning and future research avenues}

As fungi are a key component for ecosystem functioning, a major impact on future ecosystem-climate feedbacks can be expected arising from fungi compositional change in concert with changes of the whole soil microbiome in permafrost (McCalley et al., 2014). So far, the complex interplay between climate, vegetation, fungi, and microorganisms in the boreal forest ecosystem is not yet understood. To our knowledge, we conducted the first study on fungus-plant interactions and co-occurrences in the palaeo context, assessing community shifts in boreal forests as well as tundra ecosystems. However, our results can only be seen as a first proxy on future fungal community changes in response to warming as the magnitude of warming differs strongly between the studied samples and present warming and any relationship may incorporate lagged responses on decadal to millennial time-scales (Biskaborn et al., 2021).

To our knowledge, this is the first long-term dataset to show this antagonistic relationship among the fungal functional types. Our study shows that warming-related vegetation change is relatable to fungus diversity and fungal functional changes. By analogy to the past, woody taxa advancing into arctic regions in the future will result in a higher fungus diversity and a relative increase in mycorrhizae, parasites, and potentially lichens at the cost of saprotroph and yeast abundance.

Our study design does not allow a definite conclusion to be drawn as to whether or not future treeline advances might rely on the presence of specific fungal communities. As ectomycorrhizal communities in the sub-arctic tundra are generally species-rich and do not show a high host preference (Ryberg et al., 2009; 2011), major changes may not be expected. However, the investigated soils in the sub-arctic already have a long history of soil development, which does not apply to bare northern tundra sites and upper mountain areas. These are potential habitats for forest establishment from a temperature point of view but might not be favourable for a diverse soil fungus composition due to a lack of nutrients and lower temperatures.

By analogy to the results of our study, lichens do not generally suffer from warming but can be affected by the vegetation. The observed decline in lichens as a consequence of denser canopy cover 
bioRxiv preprint doi: https://doi.org/10.1101/2021.11.05.465756; this version posted November 5,2021 . The copyright holder for this preprint (which was not certified by peer review) is the author/funder, who has granted bioRxiv a license to display the preprint in perpetuity. It is made available under aCC-BY 4.0 International license.

(Cornelissen et al., 2001) may only apply to the more southerly forests. As our study only returned a few lichen OTUs, it is not possible to draw a robust conclusion here. Extensive $\mathrm{CO}_{2}$-concentration supply during experimental darkening leads to a generally quick accumulative $\mathrm{CO}_{2}$ uptake in, for example, the genus Peltigera and a subsequent relatively slow release (Badger et al., 1993), making lichens potentially valuable for the storage of future warming-induced $\mathrm{CO}_{2}$ release from soil. Further research into lichens could be promising for the development of mechanisms to support ecosystem adaptations towards changing environments.

Besides the limitation in the temporal resolution, our study suffers from limited taxonomic resolution and a complex abundance pattern. Sedimentary ancient DNA metabarcoding is a highly complex method which faces several limitations. First, it is highly susceptible to any damage and degradation which can lead to biases in the PCR products as potential taxa might be dismissed due to their short lengths (Coissac et al., 2012; Taberlet et al., 2012). Second, sometimes the reference genomes are missing and therefore identification at the relevant taxonomic resolution is not possible (Sønsteb $\varnothing$ et al., 2010). Third, different taxa possess varying amounts of copy numbers per cell which can also lead to an overrepresentation of taxa with high copy numbers while rare taxa might be missed (Behnke et al., 2011).

\section{Conclusions}

This is the first study showing spatial and temporal changes in palaeo fungus-plant covariation. Knowing which fungi influenced the growth of specific plant communities in the past will help to predict future community turnover due to varying climate. To understand palaeo community turnover in more detail, it is necessary to consider a plant's associated heterotrophic organisms in present times. This will help to place the knowledge gained in this study into better context. Additionally, our data are a great asset to the existing knowledge about boreal forests as they help to shed light on adaptation mechanisms of plants towards warming and their subsequent northward migration. Nevertheless, there are still many ecological interactions unknown which need to be addressed in future research, such as which organisms contribute to the rhizospheres of specific plants and if or how these associations change with varying climate. Despite this, our findings will already help the assessment of future tipping points in boreal forest stability.

\section{$\underline{\text { References }}$}

Allison, S. D., D. S. LeBauer, M. R. Rosario, R. Reyes, A-M. Ta, and T. M. Tran. 2009. 'Low Levels of Nitrogen Addition Stimulate Decomposition by Boreal Forest Fungi'. Soil Biology and Biochemistry 41 (2): 293-302. https://doi.org/10.1016/j.soilbio.2008.10.032.

Alsos, I.G., Y. Lammers, N.G. Yoccoz, T. Jørgensen, P. Sjögren, L. Gielly, and M. E. Edwards. 2018. 'Plant DNA Metabarcoding of Lake Sediments: How Does It Represent the Contemporary Vegetation'. PLOS ONE 13 (4): e0195403. https://doi.org/10.1371/journal.pone.0195403.

Andreev, A. A., P. E. Tarasov, V. A. Klimanov, M. Melles, O. M. Lisitsyna, and H.-W. Hubberten. 2004. 'Vegetation and Climate Changes around the Lama Lake, Taymyr Peninsula, Russia during the Late Pleistocene and Holocene'. Quaternary International 122 (1): 69-84. https://doi.org/10.1016/j.quaint.2004.01.032.

Anisimov, M. A., and I. N. Pospelov. 1999. 'The Landscape and Geobotanical Characteristics of the Levinson- Lessing Lake Basin, Byrranga Mountains, Central Taimyr'. In Land-Ocean Systems in the Siberian Arctic: Dynamics and History, edited by Heidemarie Kassens, Henning A. Bauch, Igor A. Dmitrenko, Hajo Eicken, Hans-Wolfgang Hubberten, Martin Melles, Jörn Thiede, and 
bioRxiv preprint doi: https://doi.org/10.1101/2021.11.05.465756; this version posted November 5, 2021. The copyright holder for this preprint (which was not certified by peer review) is the author/funder, who has granted bioRxiv a license to display the preprint in perpetuity. It is made available under aCC-BY 4.0 International license.

Leonid A. Timokhov, 307-27. Berlin, Heidelberg: Springer. https://doi.org/10.1007/978-3642-60134-7_27.

Asplund, J., and D. A. Wardle. 2015. 'Changes in Functional Traits of the Terricolous Lichen Peltigera aphthosa across a Retrogressive Boreal Forest Chronosequence'. The Lichenologist 47 (3): 187-95. https://doi.org/10.1017/S0024282915000092.

Asplund, J., and D. A. Wardle. 2017. 'How Lichens Impact on Terrestrial Community and Ecosystem Properties'. Biological Reviews of the Cambridge Philosophical Society 92 (3): 1720-38. https://doi.org/10.1111/brv.12305.

Atlas Arktiki. 1985. Glav. Upravl. Geodezii i Kartografii pri Sovete Ministrov SSSR.

Badger, M. R., H. Pfanz, B. Büdel, U. Heber, and O. L. Lange. 1993. 'Evidence for the Functioning of Photosynthetic $\mathrm{CO}_{2}$-Concentrating Mechanisms in Lichens Containing Green Algal and Cyanobacterial Photobionts'. Planta 191 (1): 57-70. https://doi.org/10.1007/BF00240896.

Baldrian, P., and V. Valášková. 2008. 'Degradation of Cellulose by Basidiomycetous Fungi' . FEMS Microbiology Reviews 32 (3): 501-21. https://doi.org/10.1111/j.1574-6976.2008.00106.x.

Behnke, A., M. Engel, R. Christen, M. Nebel, R. R. Klein, and T. Stoeck. 2011. 'Depicting More Accurate Pictures of Protistan Community Complexity Using Pyrosequencing of Hypervariable SSU RRNA Gene Regions'. Environmental Microbiology 13 (2): 340-49. https://doi.org/10.1111/j.1462-2920.2010.02332.x.

Bellemain, E., M. L. Davey, H. Kauserud, L. S. Epp, S. Boessenkool, E. Coissac, J. Geml, M. Edwards, E. Willerslev, G. Gussarova, P. Taberlet and C. Brochmann. 2013. 'Fungal Palaeodiversity Revealed Using High-Throughput Metabarcoding of Ancient DNA from Arctic Permafrost'. Environmental Microbiology 15 (4): 1176-89. https://doi.org/10.1111/1462-2920.12020.

Biskaborn, B. K., D. A. Subetto, L. A. Savelieva, P. S. Vakhrameeva, A. Hansche, U. Herzschuh, J. Klemm, L Heinecke, L.A. Pestryakova, H. Meyer, G. Kuhn, and B. Diekmann. 2016. 'Late Quaternary Vegetation and Lake System Dynamics in North-Eastern Siberia: Implications for Seasonal Climate Variability'. Quaternary Science Reviews 147: 406-21. https://doi.org/10.1016/j.quascirev.2015.08.014.

Biskaborn, B. K., L. Nazarova, T. Kröger, L. A. Pestryakova, L. Syrykh, G. Pfalz, U. Herzschuh, and B. Diekmann. 2021. 'Late Quaternary Climate Reconstruction and Lead-Lag Relationships of Biotic and Sediment-Geochemical Indicators at Lake Bolshoe Toko, Siberia'. Frontiers in Earth Science 9: 703. https://doi.org/10.3389/feart.2021.737353.

Biskaborn, B. K., L. Nazarova, L. A. Pestryakova, L. Syrykh, K. Funck, H. Meyer, B. Chapligin, S. Vyse, R. Gorodnichev, E. Zakharov, R. Wang, G. Schwamborn, H. L. Bailey, and B. Diekmann. 2019. 'Spatial Distribution of Environmental Indicators in Surface Sediments of Lake Bolshoe Toko, Yakutia, Russia'. Biogeosciences 16 (20): 4023-49. https://doi.org/10.5194/bg-16-40232019.

Biskaborn, B. K., S. L. Smith, J. Noetzli, H. Matthes, G. Vieira, D. A. Streletskiy, P. Schoeneich, [...], and H. Lantuit. 2019. 'Permafrost Is Warming at a Global Scale'. Nature Communications 10 (1): 264. https://doi.org/10.1038/s41467-018-08240-4.

Blaauw, M., and J. A. Christen. 2011. 'Flexible Paleoclimate Age-Depth Models Using an Autoregressive Gamma Process'. Bayesian Analysis 6 (3): 457-74. https://doi.org/10.1214/11-BA618.

Bocherens, H., E. Hofman-Kamińska, D. G. Drucker, U. Schmölcke, and R. Kowalczyk. 2015. 'European Bison as a Refugee Species? Evidence from Isotopic Data on Early Holocene Bison and Other Large Herbivores in Northern Europe'. PLOS ONE 10 (2): e0115090. https://doi.org/10.1371/journal.pone.0115090.

Botnen, S., U. Vik, T. Carlsen, P. B. Eidesen, M. L. Davey, and H. Kauserud. 2014. 'Low Host Specificity of Root-Associated Fungi at an Arctic Site'. Molecular Ecology 23 (4): 975-85. https://doi.org/10.1111/mec.12646.

Boyandin, A. N., V. P. Rudnev, V. N. Ivonin, S. V. Prudnikova, K. I. Korobikhina, M. L. Filipenko, T. G. Volova, and A. J. Sinskey. 2012. 'Biodegradation of Polyhydroxyalkanoate Films in Natural 
bioRxiv preprint doi: https://doi.org/10.1101/2021.11.05.465756; this version posted November 5,2021 . The copyright holder for this preprint (which was not certified by peer review) is the author/funder, who has granted bioRxiv a license to display the preprint in perpetuity. It is made available under aCC-BY 4.0 International license.

Environments'. Macromolecular Symposia 320 (1): 38-42.

https://doi.org/10.1002/masy.201251004.

Boyer, F., C. Mercier, A. Bonin, Y. Le Bras, P. Taberlet, and E. Coissac. 2016. 'Obitools: A Unix-Inspired Software Package for DNA Metabarcoding'. Molecular Ecology Resources 16 (1): 176-82. https://doi.org/10.1111/1755-0998.12428.

Brown, J., O. J. Ferrians Jr, J. A. Heginbottom, and E. S. Melnikov. 1997. 'Circum-Arctic Map of Permafrost and Ground-Ice Conditions'. Circum-Pacific Map. https://doi.org/10.3133/cp45.

Brundrett, M. C., and L. Tedersoo. 2018. 'Evolutionary History of Mycorrhizal Symbioses and Global Host Plant Diversity'. New Phytologist 220 (4): 1108-15. https://doi.org/10.1111/nph.14976.

Burdon, J. J., and J. Zhan. 2020. 'Climate Change and Disease in Plant Communities'. PLOS Biology 18 (11): e3000949. https://doi.org/10.1371/journal.pbio.3000949.

Carris, L. M., and A. P. Poole. 1993. 'A New Species of Protoventuria on Leaves of Vaccinium macrocarpon'. Mycologia 85 (1): 93-99. https://doi.org/10.1080/00275514.1993.12026251.

Champlot, S., C. Berthelot, M. Pruvost, E. A. Bennett, T. Grange, and E-M Geigl. 2010. 'An Efficient Multistrategy DNA Decontamination Procedure of PCR Reagents for Hypersensitive PCR Applications'. PLOS ONE 5 (9): e13042. https://doi.org/10.1371/journal.pone.0013042.

Chen, Q., L. Hou, W. Duan, P. Crous, and L. Cai. 2017. 'Didymellaceae Revisited'. Studies in Mycology 87: 105-59. https://doi.org/10.1016/j.simyco.2017.06.002.

Coissac, E., T. Riaz, and N. Puillandre. 2012. 'Bioinformatic Challenges for DNA Metabarcoding of Plants and Animals'. Molecular Ecology 21 (8): 1834-47. https://doi.org/10.1111/j.1365294X.2012.05550.x.

Compant, S., B. Duffy, J. Nowak, C. Clément, and E. Ait Barka. 2005. 'Use of Plant Growth-Promoting Bacteria for Biocontrol of Plant Diseases: Principles, Mechanisms of Action, and Future Prospects'. Applied and Environmental Microbiology 71 (9): 4951-59. https://doi.org/10.1128/AEM.71.9.4951-4959.2005.

Cornelissen, J. H. C., T. V. Callaghan, J. M. Alatalo, A. Michelsen, E. Graglia, A. E. Hartley, D. S. Hik, et al. 2001. 'Global Change and Arctic Ecosystems: Is Lichen Decline a Function of Increases in Vascular Plant Biomass?' Journal of Ecology 89 (6): 984-94. https://doi.org/10.1111/j.13652745.2001.00625.x.

Courtin, J., A. A. Andreev, E. Raschke, S. Bala, B. K. Biskaborn, S. Liu, H. Zimmermann, et al. 2021. 'Vegetation Changes in Southeastern Siberia During the Late Pleistocene and the Holocene'. Frontiers in Ecology and Evolution 9. https://doi.org/10.3389/fevo.2021.625096.

Cutler, N. A., D. L. Chaput, and C. J. van der Gast. 2014. 'Long-Term Changes in Soil Microbial Communities during Primary Succession'. Soil Biology and Biochemistry 69: 359-70. https://doi.org/10.1016/j.soilbio.2013.11.022.

Czimczik, C. I., M. W. I. Schmidt, and E.-D. Schulze. 2005. 'Effects of Increasing Fire Frequency on Black Carbon and Organic Matter in Podzols of Siberian Scots Pine Forests'. European Journal of Soil Science 56 (3): 417-28. https://doi.org/10.1111/j.1365-2389.2004.00665.x.

Deslippe, J. R., M. Hartmann, S. W. Simard, and W. W. Mohn. 2012. 'Long-Term Warming Alters the Composition of Arctic Soil Microbial Communities'. FEMS Microbiology Ecology 82 (2): 30315. https://doi.org/10.1111/j.1574-6941.2012.01350.x.

Doležal, J., V. Yakubov, and T. Hara. 2013. 'Plant Diversity Changes and Succession along Resource Availability and Disturbance Gradients in Kamchatka'. Plant Ecology 214 (3): 477-88. https://doi.org/10.1007/s11258-013-0184-z.

Drucker, D. G., C. -J. Kind, and E. Stephan. 2011. 'Chronological and Ecological Information on LateGlacial and Early Holocene Reindeer from Northwest Europe Using Radiocarbon $\left({ }^{14} \mathrm{C}\right)$ and Stable Isotope $\left({ }^{13} \mathrm{C},{ }^{15} \mathrm{~N}\right)$ Analysis of Bone Collagen: Case Study in Southwestern Germany'. Quaternary International 245 (2): 218-24. https://doi.org/10.1016/j.quaint.2011.05.007.

El-Tarabily, K. A., and K. Sivasithamparam. 2006. 'Potential of Yeasts as Biocontrol Agents of SoilBorne Fungal Plant Pathogens and as Plant Growth Promoters'. Mycoscience 47 (1): 25-35. https://doi.org/10.1007/S10267-005-0268-2. 
bioRxiv preprint doi: https://doi.org/10.1101/2021.11.05.465756; this version posted November 5, 2021. The copyright holder for this preprint (which was not certified by peer review) is the author/funder, who has granted bioRxiv a license to display the preprint in perpetuity. It is made available under aCC-BY 4.0 International license.

Fernández-Mendoza, F., A. Fleischhacker, T. Kopun, M. Grube, and L. Muggia. 2017. 'ITS1 Metabarcoding Highlights Low Specificity of Lichen Mycobiomes at a Local Scale'. Molecular Ecology 26 (18): 4811-30. https://doi.org/10.1111/mec.14244.

Finlay, R. D. 2008. 'Ecological Aspects of Mycorrhizal Symbiosis: With Special Emphasis on the Functional Diversity of Interactions Involving the Extraradical Mycelium'. Journal of Experimental Botany 59 (5): 1115-26. https://doi.org/10.1093/jxb/ern059.

Frąc, M., S. E. Hannula, M. Bełka, and M. Jędryczka. 2018. 'Fungal Biodiversity and Their Role in Soil Health'. Frontiers in Microbiology 9. https://doi.org/10.3389/fmicb.2018.00707.

Fraser, R. H., T. C. Lantz, I. Olthof, S. V. Kokelj, and R. A. Sims. 2014. 'Warming-Induced Shrub Expansion and Lichen Decline in the Western Canadian Arctic'. Ecosystems 17 (7): 1151-68. https://doi.org/10.1007/s10021-014-9783-3.

Frøslev, T. G., R. Kjøller, H. H. Bruun, R. Ejrnæs, A. K. Brunbjerg, C. Pietroni, and A. J. Hansen. 2017. 'Algorithm for Post-Clustering Curation of DNA Amplicon Data Yields Reliable Biodiversity Estimates'. Nature Communications 8 (1): 1188. https://doi.org/10.1038/s41467-017-01312$x$.

Garbelotto, M., and P. Gonthier. 2013. 'Biology, Epidemiology, and Control of Heterobasidion Species Worldwide'. Annual Review of Phytopathology 51 (1): 39-59. https://doi.org/10.1146/annurev-phyto-082712-102225.

Garnica, S., M. Weiß, B. Oertel, and F. Oberwinkler. 2005. 'A Framework for a Phylogenetic Classification in the Genus Cortinarius (Basidiomycota, Agaricales) Derived from Morphological and Molecular Data' Canadian Journal of Botany 83: 21. https://doi.org/10.1139/b05-107.

Geml, J., L. N. Morgado, T. A. Semenova, J. M. Welker, M. D. Walker, and E. Smets. 2015. 'Long-Term Warming Alters Richness and Composition of Taxonomic and Functional Groups of Arctic Fungi'. FEMS Microbiology Ecology 91 (fiv095). https://doi.org/10.1093/femsec/fiv095.

Geml, J., L. N. Morgado, and T. A. Semenova-Nelsen. 2021. 'Tundra Type Drives Distinct Trajectories of Functional and Taxonomic Composition of Arctic Fungal Communities in Response to Climate Change - Results from Long-Term Experimental Summer Warming and Increased Snow Depth'. Frontiers in Microbiology 12: 628746. https://doi.org/10.3389/fmicb.2021.628746.

Geml, J., L. N. Morgado, T. A. Semenova-Nelsen, and M. Schilthuizen. 2017. 'Changes in Richness and Community Composition of Ectomycorrhizal Fungi among Altitudinal Vegetation Types on Mount Kinabalu in Borneo'. New Phytologist 215 (1): 454-68. https://doi.org/10.1111/nph.14566.

Geml, J., T. A. Semenova, L. N. Morgado, and J. M. Welker. 2016. 'Changes in Composition and Abundance of Functional Groups of Arctic Fungi in Response to Long-Term Summer Warming'. Biology Letters 12 (11): 20160503. https://doi.org/10.1098/rsbl.2016.0503.

Goodwin, S., J. D. McPherson, and W. R. McCombie. 2016. 'Coming of Age: Ten Years of nextGeneration Sequencing Technologies'. Nature Reviews Genetics 17 (6): 333-51. https://doi.org/10.1038/nrg.2016.49.

He, J., L. Tedersoo, A. Hu, C. Han, D. He, H. Wei, M. Jiao, et al. 2017. 'Greater Diversity of Soil Fungal Communities and Distinguishable Seasonal Variation in Temperate Deciduous Forests Compared with Subtropical Evergreen Forests of Eastern China'. FEMS Microbiology Ecology 93 (7). https://doi.org/10.1093/femsec/fix069.

Hernández-Fernández, M., G. Cordero-Bueso, M. Ruiz-Muñoz, and J. M. Cantoral. 2021. 'Culturable Yeasts as Biofertilizers and Biopesticides for a Sustainable Agriculture: A Comprehensive Review'. Plants 10 (5): 822. https://doi.org/10.3390/plants10050822.

Hosseini-Nasabnia, Z., K. Van Rees, and V. Vujanovic. 2016. 'Preventing Unwanted Spread of Invasive Fungal Species in Willow (Salix spp.) Plantations'. Canadian Journal of Plant Pathology 38 (3): 325-37. https://doi.org/10.1080/07060661.2016.1228697. 
bioRxiv preprint doi: https://doi.org/10.1101/2021.11.05.465756; this version posted November 5, 2021. The copyright holder for this preprint (which was not certified by peer review) is the author/funder, who has granted bioRxiv a license to display the preprint in perpetuity. It is made available under aCC-BY 4.0 International license.

Huang, S., K. R. Stoof-Leichsenring, S. Liu, J. Courtin, A. A. Andreev, L. A. Pestryakova, and U. Herzschuh. 2020. 'Plant Sedimentary Ancient DNA from Far East Russia Covering the Last 28 Ka Reveals Different Assembly Rules in Cold and Warm Climates'. BioRxiv, December, 2020.12.11.406108. https://doi.org/10.1101/2020.12.11.406108.

Ishida, T. A., K. Nara, and T. Hogetsu. 2007. 'Host Effects on Ectomycorrhizal Fungal Communities: Insight from Eight Host Species in Mixed Conifer-Broadleaf Forests'. New Phytologist 174 (2): 430-40. https://doi.org/10.1111/j.1469-8137.2007.02016.x.

Iznova, T., and J. Rukšènienè. 2012. 'Ascomycete Species New to Lithuania'. Botanica Lithuanica 18 (1): 35-39. https://doi.org/10.2478/v10279-012-0005-7.

Kachalkin, A. V., and A. M. Yurkov. 2012. 'Yeast Communities in Sphagnum Phyllosphere along the Temperature-Moisture Ecocline in the Boreal Forest-Swamp Ecosystem and Description of Candida sphagnicola sp. nov.' Antonie van Leeuwenhoek 102 (1): 29-43. https://doi.org/10.1007/s10482-012-9710-6.

Kandror, O., N. Bretschneider, E. Kreydin, D. Cavalieri, and A. L Goldberg. 2004. 'Yeast Adapt to NearFreezing Temperatures by STRE/Msn2,4-Dependent Induction of Trehalose Synthesis and Certain Molecular Chaperones'. Molecular Cell 13 (6): 771-81. https://doi.org/10.1016/S1097-2765(04)00148-0.

Kanz, C., P. Aldebert, N. Althorpe, W. Baker, A. Baldwin, K. Bates, P. Browne, et al. 2005. 'The EMBL Nucleotide Sequence Database'. Nucleic Acids Research 33 (suppl_1): D29-33. https://doi.org/10.1093/nar/gki098.

Kerkhoff, A. J., P. E. Moriarty, and M. D. Weiser. 2014. 'The Latitudinal Species Richness Gradient in New World Woody Angiosperms Is Consistent with the Tropical Conservatism Hypothesis'. Proceedings of the National Academy of Sciences 111 (22): 8125-30. https://doi.org/10.1073/pnas.1308932111.

Kistenich, S., R. Halvorsen, A. Schrøder-Nielsen, L. Thorbek, E. Timdal, and M. Bendiksby. 2019. 'DNA Sequencing Historical Lichen Specimens'. Frontiers in Ecology and Evolution 7. https://doi.org/10.3389/fevo.2019.00005.

Klemm, J., U. Herzschuh, and L. A. Pestryakova. 2016. 'Vegetation, Climate and Lake Changes over the Last 7000 Years at the Boreal Treeline in North-Central Siberia'. Quaternary Science Reviews 147: 422-34. https://doi.org/10.1016/j.quascirev.2015.08.015.

Konstantinov, A. F. 2000. 'Environmental problems of Lake Bolshoe Toko, Lakes of Cold Environments, part V: Resource Study', In: Resource Use, Ecology and Nature Protection Issue, Yakutsk: 85-93.

Kreveld, S. van, M. Sarnthein, H. Erlenkeuser, P. Grootes, S. Jung, M. J. Nadeau, U. Pflaumann, and A. Voelker. 2000. 'Potential Links between Surging Ice Sheets, Circulation Changes, and the Dansgaard-Oeschger Cycles in the Irminger Sea, 60-18 Kyr'. Paleoceanography 15 (4): 42542. https://doi.org/10.1029/1999PA000464.

Kurek, E., T. Korniłłowicz-kowalska, A. Słomka, and J. Melke. 2007. 'Characteristics of Soil Filamentous Fungi Communities Isolated from Various Micro-Relief Forms in the High Arctic Tundra (Bellsund Region, Spitsbergen)'. Polar Research 28: 57-73.

Laperriere, G., P-L. Chagnon, R. Giguère-Tremblay, A. Morneault, D. Bisson, V. Maire, and H. Germain. 2019. 'Estimation of Fungal Diversity and Identification of Major Abiotic Drivers Influencing Fungal Richness and Communities in Northern Temperate and Boreal Quebec Forests'. Forests 10 (12): 1096. https://doi.org/10.3390/f10121096.

Lebas, E., S. Krastel, B. Wagner, R. Gromig, G. Fedorov, M. Baumer, N. Kostromina, and H. Haflidason. 2019. 'Seismic Stratigraphical Record of Lake Levinson-Lessing, Taymyr Peninsula: Evidence for Ice-Sheet Dynamics and Lake-Level Fluctuations since the Early Weichselian'. Boreas 48 (2): 470-87. https://doi.org/10.1111/bor.12381.

Leski, T., and M. Rudawska. 2012. 'Ectomycorrhizal Fungal Community of Naturally Regenerated European Larch (Larix decidua) Seedlings'. Symbiosis 56 (2): 45-53. https://doi.org/10.1007/s13199-012-0164-4. 
bioRxiv preprint doi: https://doi.org/10.1101/2021.11.05.465756; this version posted November 5,2021 . The copyright holder for this preprint (which was not certified by peer review) is the author/funder, who has granted bioRxiv a license to display the preprint in perpetuity. It is made available under aCC-BY 4.0 International license.

Liao, H-L., Y. Chen, and R. Vilgalys. 2016. 'Metatranscriptomic Study of Common and Host-Specific Patterns of Gene Expression between Pines and Their Symbiotic Ectomycorrhizal Fungi in the Genus Suillus'. PLOS Genetics 12 (10): e1006348. https://doi.org/10.1371/journal.pgen.1006348.

Liu, S., K. R. Stoof-Leichsenring, S. Kruse, L. A. Pestryakova, U. Herzschuh. 2020. 'Holocene Vegetation and Plant Diversity Changes in the North-Eastern Siberian Treeline Region From Pollen and Sedimentary Ancient DNA'. Frontiers in Ecology and Evolution 8: 18.

Lydolph, M. C., J. Jacobsen, P. Arctander, M. T. P. Gilbert, D. A. Gilichinsky, A. J. Hansen, E. Willerslev, and L. Lange. 2005. 'Beringian Paleoecology Inferred from Permafrost-Preserved Fungal DNA'. Applied and Environmental Microbiology 71 (2): 1012-17. https://doi.org/10.1128/AEM.71.2.1012-1017.2005.

Marschner, H., and B. Dell. 1994. 'Nutrient Uptake in Mycorrhizal Symbiosis'. Plant and Soil 159 (1): 89-102. https://doi.org/10.1007/BF00000098.

Matheny, P. B., A. M. Hobbs, and F. Esteve-Raventós. 2020. 'Genera of Inocybaceae: New Skin for the Old Ceremony'. Mycologia 112 (1): 83-120. https://doi.org/10.1080/00275514.2019.1668906.

Matsuoka, S., H. Doi, S. Masumoto, R. Kitagawa, K. Nishizawa, K. Tanaka, M. Hasegawa, et al. 2021. 'Taxonomic, Functional, and Phylogenetic Diversity of Fungi in a Forest-Tundra Ecotone in Québec'. Polar Science, Arctic Challenge for Sustainability Project (ArCS), 27 (March): 100594. https://doi.org/10.1016/j.polar.2020.100594.

McCalley, C. K., B. J. Woodcroft, S. B. Hodgkins, R. A. Wehr, E-H. Kim, R. Mondav, P. M. Crill, et al. 2014. 'Methane Dynamics Regulated by Microbial Community Response to Permafrost Thaw'. Nature 514 (7523): 478-81. https://doi.org/10.1038/nature13798.

McGuire, K. L., S. D. Allison, N. Fierer, and K. K. Treseder. 2013. 'Ectomycorrhizal-Dominated Boreal and Tropical Forests Have Distinct Fungal Communities, but Analogous Spatial Patterns across Soil Horizons'. PLOS ONE 8 (7): e68278. https://doi.org/10.1371/journal.pone.0068278.

Mercier, C., F. Boyer, A. Bonin, and E. Coissac. 2013. 'SUMATRA and SUMACLUST: Fast and Exact Comparison and Clustering of Sequences'. 2013.

Miyamoto, Y., A. V. Danilov, and S. V. Bryanin. 2021. 'The Dominance of Suillus Species in Ectomycorrhizal Fungal Communities on Larix gmelinii in a Post-Fire Forest in the Russian Far East'. Mycorrhiza 31 (1): 55-66. https://doi.org/10.1007/s00572-020-00995-3.

Mundra, S., R. Halvorsen, H. Kauserud, M. Bahram, L. Tedersoo, B. Elberling, E. J. Cooper, and P. Bronken Eidesen. 2016. 'Ectomycorrhizal and Saprotrophic Fungi Respond Differently to Long-Term Experimentally Increased Snow Depth in the High Arctic'. MicrobiologyOpen 5 (5): 856-69. https://doi.org/10.1002/mbo3.375.

Naranjo-Ortiz, M. A., and T. Gabaldón. 2019. 'Fungal Evolution: Major Ecological Adaptations and Evolutionary Transitions'. Biological Reviews of the Cambridge Philosophical Society 94 (4): 1443-76. https://doi.org/10.1111/brv.12510.

Nash, T. H. 2002. Lichen Flora of the Greater Sonoran Desert Region: Most of the Microlichens, Balance of the Macrolichens, and Lichenicolous Fungi. Lichens Unlimited, Arizona State University.

Nassar, A. H., K. A. El-Tarabily, and K. Sivasithamparam. 2005. 'Promotion of Plant Growth by an Auxin-Producing Isolate of the Yeast Williopsis saturnus Endophytic in Maize (Zea mays L.) Roots'. Biology and Fertility of Soils 42 (2): 97-108. https://doi.org/10.1007/s00374-0050008-y.

Nelsen, M. P., and A. Gargas. 2009. 'Symbiont Flexibility in Thamnolia vermicularis (Pertusariales: Icmadophilaceae)'. The Bryologist 112 (2): 404-17.

Niemeyer, B., L. S. Epp, K. R. Stoof-Leichsenring, L. A. Pestryakova, and U. Herzschuh. 2017. 'A Comparison of Sedimentary DNA and Pollen from Lake Sediments in Recording Vegetation 
bioRxiv preprint doi: https://doi.org/10.1101/2021.11.05.465756; this version posted November 5, 2021. The copyright holder for this preprint (which was not certified by peer review) is the author/funder, who has granted bioRxiv a license to display the preprint in perpetuity. It is made available under aCC-BY 4.0 International license.

Composition at the Siberian Treeline'. Molecular Ecology Resources 17 (6): e46-62. https://doi.org/10.1111/1755-0998.12689.

Nilsson, R. H., E. Kristiansson, M. Ryberg, and K-H. Larsson. 2005. 'Approaching the Taxonomic Affiliation of Unidentified Sequences in Public Databases - an Example from the Mycorrhizal Fungi'. BMC Bioinformatics 6 (1): 178. https://doi.org/10.1186/1471-2105-6-178.

Nilsson, R. H., K-H. Larsson, A. F. S. Taylor, J. Bengtsson-Palme, T. S. Jeppesen, D. Schigel, P. Kennedy, et al. 2019. 'The UNITE Database for Molecular Identification of Fungi: Handling Dark Taxa and Parallel Taxonomic Classifications'. Nucleic Acids Research 47 (D1): D259-64. https://doi.org/10.1093/nar/gky1022.

Öpik, M., M. Moora, M. Zobel, Ü. Saks, R. Wheatley, F. Wright, and T. Daniell. 2008. 'High Diversity of Arbuscular Mycorrhizal Fungi in a Boreal Herb-Rich Coniferous Forest'. New Phytologist 179 (3): 867-76. https://doi.org/10.1111/j.1469-8137.2008.02515.x.

Otrosina, W. J., and F. W. Cobb. 1989. 'Biology, Ecology, and Epidemiology of Heterobasidion annosum'. USDA Forest Service General Technical Report PSW-116, 33 pp. /paper/Biology\%2C-Ecology\%2C-and-Epidemiology-of-annosum-OtrosinaCobb/1dc1ea2570a97e714aafb41eaac9f56ffa41dbd8.

Palamarchuk, M., and D. Kirillov. n.d. 'Fungi (Agaricoid Basidiomycetes) of the Pechoro-llych Reserve (Komi Republic, Russia)'. Accessed 10 June 2021. https://doi.org/10.15468/o9jk3m.

Palm, M. E., and E. L. Stewart. 1984. 'In Vitro Synthesis of Mycorrhizae between Presumed Specific and Nonspecific Pinus + Suillus Combinations'. Mycologia 76 (4): 579-600. https://doi.org/10.2307/3793215.

Pande, V., U. T. Palni, and S. P. Singh. 2004. 'Species Diversity of Ectomycorrhizal Fungi Associated with Temperate Forest of Western Himalaya: A Preliminary Assessment'. Current Science 86 (12): 1619-23.

Parducci, L., K. D. Bennett, G. F. Ficetola, I. Greve Alsos, Y. Suyama, J. R. Wood, and M. Winther Pedersen. 2017. 'Ancient Plant DNA in Lake Sediments'. New Phytologist 214 (3): 924-42. https://doi.org/10.1111/nph.14470.

Park, J-H., I. Pavlov, M-J. Kim, M. Soo Park, S-Y. Oh, K. Hyeong Park, J. Fong, and Y. Woon Lim. 2020. 'Investigating Wood Decaying Fungi Diversity in Central Siberia, Russia Using ITS Sequence Analysis and Interaction with Host Trees'. Sustainability 12: 2535. https://doi.org/10.3390/su12062535.

Põlme, S., M. Bahram, H. Jacquemyn, P. Kennedy, P. Kohout, M. Moora, J. Oja, M. Öpik, L. Pecoraro, and L. Tedersoo. 2018. 'Host Preference and Network Properties in Biotrophic Plant-Fungal Associations'. New Phytologist 217 (3): 1230-39. https://doi.org/10.1111/nph.14895.

Polyakova, A., and I. Chernov. 2001. 'Yeast Diversity in Hydromorphic Soils with Reference to a Grass-Sphagnum Wetland in Western Siberia and a Hummocky Tundra Region at Cape Barrow (Alaska)'. Microbiology 70: 617-23. https://doi.org/10.1023/A:1012328710111.

Porada, P., A. Ekici, and C. Beer. 2016. 'Effects of Bryophyte and Lichen Cover on Permafrost Soil Temperature at Large Scale'. The Cryosphere 10 (5): 2291-2315. https://doi.org/10.5194/tc10-2291-2016.

Quince, C., A. Lanzén, T. P. Curtis, R. J. Davenport, N. Hall, I. M. Head, L. F. Read, and W. T. Sloan. 2009. 'Accurate Determination of Microbial Diversity from 454 Pyrosequencing Data'. Nature Methods 6 (9): 639-41. https://doi.org/10.1038/nmeth.1361.

R Core Team. 2020. R Foundation for Statistical Computing, Vienna, Austria. https://www.Rproject.org/.

Reimer, P. J., Austin, W. E.N., Bard, E. Bayliss, A. Blackwell, Paul G., Ramsey, C. B. Butzin, Martin, Cheng, Hai, [...], S. Talamo. 2020. 'The IntCal20 Northern Hemisphere Radiocarbon Age Calibration Curve (0-55 cal kBP)'. Radiocarbon 62(4): 725-757. https://doi.org/10.1017/RDC.2020.41. 
bioRxiv preprint doi: https://doi.org/10.1101/2021.11.05.465756; this version posted November 5, 2021. The copyright holder for this preprint (which was not certified by peer review) is the author/funder, who has granted bioRxiv a license to display the preprint in perpetuity. It is made available under aCC-BY 4.0 International license.

Renker, C., J. Alphei, and F. Buscot. 2003. 'Soil Nematodes Associated with the Mammal Pathogenic Fungal Genus Malassezia (Basidiomycota: Ustilaginomycetes) in Central European Forests'. Biology and Fertility of Soils 37 (1): 70-72. https://doi.org/10.1007/s00374-002-0556-3.

Romero-Olivares, A. L., G. Meléndrez-Carballo, A. Lago-Lestón, and K. K. Treseder. 2019. 'Soil Metatranscriptomes Under Long-Term Experimental Warming and Drying: Fungi Allocate Resources to Cell Metabolic Maintenance Rather Than Decay'. Frontiers in Microbiology 10. https://doi.org/10.3389/fmicb.2019.01914.

Romero-Olivares, A. L., J. W. Taylor, and K. K. Treseder. 2015. 'Neurospora discreta as a Model to Assess Adaptation of Soil Fungi to Warming'. BMC Evolutionary Biology 15 (1): 198. https://doi.org/10.1186/s12862-015-0482-2.

Russian Institute of Hydrometeorological Information: World Data Center, Available at Http://Meteo.Ru/English/Climate/Temp.Php (Last Access: 18. June 2021), 2021.

Ryberg, M., M. Andreasen, and R. G. Björk. 2011. 'Weak Habitat Specificity in Ectomycorrhizal Communities Associated with Salix herbacea and Salix polaris in Alpine Tundra'. Mycorrhiza 21 (4): 289-96. https://doi.org/10.1007/s00572-010-0335-1.

Ryberg, M., E. Larsson, and U. Molau. 2009. 'Ectomycorrhizal Diversity on Dryas octopetala and Salix reticulata in an Alpine Cliff Ecosystem'. Arctic, Antarctic, and Alpine Research 41 (4): 506-14. https://doi.org/10.1657/1938-4246-41.4.506.

Safronova, I., and T. Yurkovsksya. 2019. 'The Latitudinal Distribution of Vegetation Cover in Siberia'. BIO Web of Conferences 16: 00047. https://doi.org/10.1051/bioconf/20191600047.

Santos, A., A. Sánchez, and D. Marquina. 2004. 'Yeasts as Biological Agents to Control Botrytis cinerea'. Microbiological Research 159 (4): 331-38. https://doi.org/10.1016/j.micres.2004.07.001.

Scheidt, S., R. Egli, M. Lenz, C. Rolf, K. Fabian, and M. Melles. 2021. 'Mineral Magnetic Characterization of High-Latitude Sediments from Lake Levinson-Lessing, Siberia'. Geophysical Research Letters 48 (May): e2021GL093026. https://doi.org/10.1029/2021GL093026.

Schiro, G., P. Colangeli, and M. E. H. Müller. 2019. 'A Metabarcoding Analysis of the Mycobiome of Wheat Ears Across a Topographically Heterogeneous Field'. Frontiers in Microbiology 10. https://doi.org/10.3389/fmicb.2019.02095.

Schulze, E-D., and H. A. Mooney. 2012. Biodiversity and Ecosystem Function. Springer Science \& Business Media.

Seeber, P, B. von Hippel, H. Kauserud, U. Löber, K.R. Stoof-Leichsenring, U. Herzschuh, L.S. Epp. 2021. 'Fungal biodiversity in Arctic palaeoecosystems assessed by metabarcoding of lake sedimentary ancient DNA'. bioRxiv. https://doi.org/10.1101/2021.11.02.462738

Seifert, K. A. 2009. 'Progress towards DNA Barcoding of Fungi'. Molecular Ecology Resources 9 (s1): 83-89. https://doi.org/10.1111/j.1755-0998.2009.02635.x.

Sheard, J. W. 1977. 'Paleogeography, Chemistry and Taxonomy of the Lichenized Ascomycetes Dimelaena and Thamnolia'. The Bryologist 80 (1): 100-118. https://doi.org/10.2307/3242516.

Shevtsova, I., B. Heim, S. Kruse, J. Schröder, E. I. Troeva, L. A. Pestryakova, E. S. Zakharov, and U. Herzschuh. 2020. 'Strong Shrub Expansion in Tundra-Taiga, Tree Infilling in Taiga and Stable Tundra in Central Chukotka (North-Eastern Siberia) between 2000 and 2017'. Environmental Research Letters 15 (8): 085006. https://doi.org/10.1088/1748-9326/ab9059.

Slaght, J. C., B. Milakovsky, D. A. Maksimova, I. V. Seryodkin, V. A. Zaitsev, A. M. Panichev, and D. G. Miquelle. 2019. 'Anthropogenic Influences on the Distribution of a Vulnerable Coniferous Forest Specialist: Habitat Selection by the Siberian Musk Deer Moschus moschiferus'. Oryx 53 (1): 174-80. https://doi.org/10.1017/S0030605316001617.

Smith, J. E., K. A. Johnson, and E. Cázares. 1998. 'Vesicular Mycorrhizal Colonization of Seedlings of Pinaceae and Betulaceae after Spore Inoculation with Glomus intraradices'. Mycorrhiza 7 (6): 279-85. https://doi.org/10.1007/s005720050193. 
bioRxiv preprint doi: https://doi.org/10.1101/2021.11.05.465756; this version posted November 5, 2021. The copyright holder for this preprint (which was not certified by peer review) is the author/funder, who has granted bioRxiv a license to display the preprint in perpetuity. It is made available under aCC-BY 4.0 International license.

Soininen, E. M., G. Gauthier, F. Bilodeau, D. Berteaux, L. Gielly, P. Taberlet, G. Gussarova, et al. 2015. 'Highly Overlapping Winter Diet in Two Sympatric Lemming Species Revealed by DNA Metabarcoding'. PloS One 10 (1): e0115335. https://doi.org/10.1371/journal.pone.0115335.

Sønstebø, J. H., L. Gielly, A. K. Brysting, R. Elven, M. Edwards, J. Haile, E. Willerslev, et al. 2010. 'Using Next-Generation Sequencing for Molecular Reconstruction of Past Arctic Vegetation and Climate'. Molecular Ecology Resources 10 (6): 1009-18. https://doi.org/10.1111/j.17550998.2010.02855.x.

Stoof-Leichsenring, K., U. Herzschuh, L. Pestrayakova, J. Klemm, L. Epp, and R. Tiedemann. 2015. 'Genetic Data from Algae Sedimentary DNA Reflect the Influence of Environment over Geography'. Scientific Reports 5: 12924. https://doi.org/10.1038/srep12924.

Svendsen, J. I., H. Alexanderson, V. I. Astakhov, I. Demidov, J. A. Dowdeswell, S. Funder, V. Gataullin, et al. 2004. 'Late Quaternary Ice Sheet History of Northern Eurasia'. Quaternary Science Reviews 23 (11): 1229-71. https://doi.org/10.1016/j.quascirev.2003.12.008.

Swann, G. E. A., A. W. Mackay, M. J. Leng, and F. Demory. 2005. 'Climatic Change in Central Asia during MIS 3/2: A Case Study Using Biological Responses from Lake Baikal'. Global and Planetary Change 46 (1): 235-53. https://doi.org/10.1016/j.gloplacha.2004.09.019.

Taberlet, P., E. Coissac, F. Pompanon, C. Brochmann, and E. Willerslev. 2012. 'Towards NextGeneration Biodiversity Assessment Using DNA Metabarcoding'. Molecular Ecology 21 (8): 2045-50. https://doi.org/10.1111/j.1365-294X.2012.05470.x.

Taberlet, P., E. Coissac, F. Pompanon, L. Gielly, C. Miquel, A. Valentini, T. Vermat, G. Corthier, C. Brochmann, and E. Willerslev. 2007. 'Power and Limitations of the Chloroplast TrnL (UAA) Intron for Plant DNA Barcoding'. Nucleic Acids Research 35 (3): e14. https://doi.org/10.1093/nar/gkl938.

Talas, L., N. Stivrins, S. Veski, L. Tedersoo, and V. Kisand. 2021. 'Sedimentary Ancient DNA (SedaDNA) Reveals Fungal Diversity and Environmental Drivers of Community Changes throughout the Holocene in the Present Boreal Lake Lielais Svētinu (Eastern Latvia)'. Microorganisms 9 (4): 719. https://doi.org/10.3390/microorganisms9040719.

Taylor, T., and J. Osborn. 1996. 'The Importance of Fungi in Shaping the Paleoecosystem'. https://doi.org/10.1016/0034-6667(95)00086-0.

Tchebakova, N M, E Parfenova, and A J Soja. 2009. 'The Effects of Climate, Permafrost and Fire on Vegetation Change in Siberia in a Changing Climate'. Environmental Research Letters 4 (4): 045013. https://doi.org/10.1088/1748-9326/4/4/045013.

Tedersoo, L., M. Mett, T. A. Ishida, and M. Bahram. 2013. 'Phylogenetic Relationships among Host Plants Explain Differences in Fungal Species Richness and Community Composition in Ectomycorrhizal Symbiosis'. New Phytologist 199 (3): 822-31. https://doi.org/10.1111/nph.12328.

Thormann, M. N. 2006. 'Diversity and Function of Fungi in Peatlands: A Carbon Cycling Perspective'. Canadian Journal of Soil Science 86 (Special Issue): 281-93. https://doi.org/10.4141/S05-082.

Timling, I., A. Dahlberg, D. A. Walker, M. Gardes, J. Y. Charcosset, J. M. Welker, and D. L. Taylor. 2012. 'Distribution and Drivers of Ectomycorrhizal Fungal Communities across the North American Arctic'. Ecosphere 3 (11): art111. https://doi.org/10.1890/ES12-00217.1.

Toljander, J. F., U. Eberhardt, Y. K. Toljander, L. R. Paul, and A. F. S. Taylor. 2006. 'Species Composition of an Ectomycorrhizal Fungal Community along a Local Nutrient Gradient in a Boreal Forest'. New Phytologist 170 (4): 873-84. https://doi.org/10.1111/j.14698137.2006.01718.x.

Treseder, K. K., Y. Marusenko, A. L. Romero-Olivares, and M. R. Maltz. 2016. 'Experimental Warming Alters Potential Function of the Fungal Community in Boreal Forest'. Global Change Biology 22 (10): 3395-3404. https://doi.org/10.1111/gcb.13238.

Treseder, K. K., K. M. Turner, and M. C. Mack. 2007. 'Mycorrhizal Responses to Nitrogen Fertilization in Boreal Ecosystems: Potential Consequences for Soil Carbon Storage'. Global Change Biology 13 (1): 78-88. https://doi.org/10.1111/j.1365-2486.2006.01279.x. 
bioRxiv preprint doi: https://doi org/10.1101/2021.11.05.465756; this version posted November 5, 2021. The copyright holder for this preprint (which was not certified by peer review) is the author/funder, who has granted bioRxiv a license to display the preprint in perpetuity. It is made available under aCC-BY 4.0 International license.

Van Geel, B.. 2001. 'Non-Pollen Palynomorphs'. In Tracking Environmental Change Using Lake Sediments, Vol. 3: Terrestrial, Algal, and Siliceous Indicators, edited by John P. Smol, H. John B. Birks, William M. Last, Raymond S. Bradley, and Keith Alverson, 99-119. Developments in Paleoenvironmental Research. Dordrecht: Springer Netherlands. https://doi.org/10.1007/0306-47668-1_6.

Voříšková, J., B. Elberling, and A. Priemé. 2019. 'Fast Response of Fungal and Prokaryotic Communities to Climate Change Manipulation in Two Contrasting Tundra Soils'. Environmental Microbiome 14 (1): 6. https://doi.org/10.1186/s40793-019-0344-4.

Wagg, C., M. Pautler, H. B. Massicotte, and R. L. Peterson. 2008. 'The Co-Occurrence of Ectomycorrhizal, Arbuscular Mycorrhizal, and Dark Septate Fungi in Seedlings of Four Members of the Pinaceae'. Mycorrhiza 18 (2): 103-10. https://doi.org/10.1007/s00572-0070157-y.

Wallenstein, M. D., S. McMahon, and J. Schimel. 2007. 'Bacterial and Fungal Community Structure in Arctic Tundra Tussock and Shrub Soils: Community Structure in Arctic Tundra Tussock and Shrub Soils'. FEMS Microbiology Ecology 59 (2): 428-35. https://doi.org/10.1111/j.15746941.2006.00260.x.

Wickham, H.. 2016. ggplot2: Elegant Graphics for Data Analysis. 2nd ed. Use R! Springer International Publishing. https://doi.org/10.1007/978-3-319-24277-4.

Willerslev, E., J. Davison, M. Moora, M. Zobel, E. Coissac, M. E. Edwards, E. D. Lorenzen, et al. 2014. 'Fifty Thousand Years of Arctic Vegetation and Megafaunal Diet'. Nature 506 (7486): 47-51. https://doi.org/10.1038/nature12921.

Wright, B., L. L. St. Clair, and S. D. Leavitt. 2019. 'Is Targeted Community DNA Metabarcoding Suitable for Biodiversity Inventories of Lichen-Forming Fungi?' Ecological Indicators 98: 81220. https://doi.org/10.1016/j.ecolind.2018.11.061.

Yang, T., J. M. Adams, Y. Shi, J-S. He, X. Jing, L. Chen, L. Tedersoo, and H. Chu. 2017. 'Soil Fungal Diversity in Natural Grasslands of the Tibetan Plateau: Associations with Plant Diversity and Productivity'. New Phytologist 215 (2): 756-65. https://doi.org/10.1111/nph.14606.

Yurkov, A.M., M. Kemler, and D. Begerow. 2012. 'Assessment of Yeast Diversity in Soils under Different Management Regimes'. Fungal Ecology 5 (1): 24-35. https://doi.org/10.1016/j.funeco.2011.07.004.

Zhang, T., N-F. Wang, H-Y. Liu, Y-Q. Zhang, and L-Y. Yu. 2016. 'Soil PH Is a Key Determinant of Soil Fungal Community Composition in the Ny-Ålesund Region, Svalbard (High Arctic)'. Frontiers in Microbiology 0. https://doi.org/10.3389/fmicb.2016.00227.

Zhurbenko, M. P., and L. S. Yakovchenko. 2014. 'A New Species, Sagediopsis vasilyevae, and Other Lichenicolous Fungi from Zabaikal'skii Territory of Russia, Southern Siberia'. Folia Cryptogamica Estonica 51 (July): 121-30. https://doi.org/10.12697/fce.2014.51.14.

Zobel, M., J. Davison, M. E. Edwards, C. Brochmann, E. Coissac, P. Taberlet, E. Willerslev, and M. Moora. 2018. 'Ancient Environmental DNA Reveals Shifts in Dominant Mutualisms during the Late Quaternary'. Nature Communications 9 (1): 139. https://doi.org/10.1038/s41467017-02421-3. 
bioRxiv preprint doi: https://doi org/10.1101/2021.11.05.465756; this version posted November 5,2021 . The copyright holder for this preprint (which was not certified by peer review) is the author/funder, who has granted bioRxiv a license to display the preprint in perpetuity. It is made available under aCC-BY 4.0 International license.

\section{Declarations}

\section{Funding}

This research has been funded by the European Research Council (ERC) under the European Union's Horizon 2020 Research and Innovation Programme (Grant Agreement No. 772852, ERC Consolidator Grant "Glacial Legacy") and the Initiative and Networking Fund of the Helmholtz Association.

\section{Conflict of interest/Competing interests}

Hereby we confirm, that this paper has not been published anywhere else and has not been submitted to another journal for consideration. All authors have approved the manuscript and agree with its submission to Fungal Diversity.

\section{Availability of data and material}

The data are available under $x x x x$ and will be publicly available after the acceptance of the manuscript.

Pangaea: Metadata of the cores and links to existing Pangaea entries

Dryad: Fungal DNA Dataset (Raw data and scripts)

Dryad: plant DNA Dataset (Raw data and scripts)

\section{Author contribution}

The study was designed by UH, KSL, BvH; KSL supervised and BvH conducted the experimental lab work; BvH analysed the data under supervision of UH and KSL; LS sampled the cores and supervised the DNA extractions; PS and LE performed the bioinformatic evaluation of the marker; MM retrieved the sediment core of Lake Lama; BD led the projects on Kyutyunda and Bolshoe Toko; BB retrieved and dated the sediment cores including age depth modelling of Bolshoe Toko, Kyutyunda, $\mathrm{CH} 12$ and Levinson Lessing; BvH dated Lama and performed the age modelling; BvH supervised by UH wrote a first version of the manuscript; all authors commented on the first and revised version of the manuscript. 